\title{
EXPERIMENTAL STUDY OF STABILIZATION OF EXPANSIVE SOIL USING THE MIXTURE OF MARBLE DUST, RICE HUSK ASH AND CEMENT FOR SUB-GRADE ROAD CONSTRUCTION: A CASE STUDY OF WOLDIA TOWN
}

\author{
Mulugeta Fentaw ${ }^{1 *}$, Esayas Alemayehu ${ }^{2}$, Anteneh Geremew ${ }^{2}$ \\ ${ }^{1}$ Woldia University, Department of Civil Engineering \\ 2 Jimma University, Faculty of Civil and Environmental Engineering \\ Date received: 17/02/2021 Date accepted: 04/09/2021 \\ *Corresponding author's email: mulugetafentaw21 @ gmail.com \\ DOI: $10.33736 /$ jcest.3977.2021
}

\begin{abstract}
Understanding the behavior of expansive soil and adopting the appropriate control measures should be great for civil engineers. Extensive research has been going on to find the solutions associated with problems of expansive soils. There have been many methods available to control the expansiveness of these soils. The removal of expansive soils and replacement with suitable material has been widely practiced worldwide. Reasonable material is available within economic distances; however, suitable materials is not readily an available in urban areas for borrowing, which has to be hauled from a long distance. Instead of borrowing suitable soil from a long distance away, after stabilization with cost effective and readily available industrial and agricultural waste materials, it is economical to use locally available plastic soil. Such wastage products are also used to minimize environmental hazards such as $\mathrm{CO}_{2}$ in the atmosphere to minimize the percentage of industrial products used for stabilization, such as cement. Marble dust (MD), an industrial waste product, Rice husk ash (RHA), agricultural waste products, and cement are industrial products in this present study. The general objective of study was to examine the effects of poor subgrade soil stabilization using the mixture of MD, RHA and cement to enhance substandard soil engineering properties to be used as subgrade materials. Moisture content, Atterberg limits, grain size analysis, soil classification, free swell index, basic gravity, compaction (maximum dry density, optimum moisture content) and CBR value test have been calculated in this analysis. The design of the analysis followed by the experimental method of study were adopted, which started with sample selection. A disturbed samples was collected from the pit at a depth of $1.5 \mathrm{~m}$ to $2 \mathrm{~m}$ from ground level in order to avoid the inclusion of organic matter by considering the free swell index value and observation was considered. The chemical analysis of MD and RHA was conducted in laboratory and the main oxides are $\left(\mathrm{SiO}_{2}+\mathrm{Al}_{2} \mathrm{O}_{3}+\mathrm{Fe}_{2} \mathrm{O}_{3}\right)$ were $70.13 \%$ for RHA and $42.43 \%$ for MD. The RHA chemical properties satisfy the requirement, while MD did not meet the requirement of ASTM C 618. The Gomata Teachers' Condominium (GTC) soil sample laboratory result have $42.72 \%$ plastic index (PI), $85 \%$ free swell index and its CBR value of $2.265 \%$. The Millennium Secondary school (MSS) soil sample has a 48.79\% PI, 87\% free swell index and $2.121 \%$ CBR value. Therefore this soil samples are highly expansive were checked before any stabilizations process based on their plasticity index and CBR value based on standard specification requirement, then stabilization was achieved by stabilization by proposed $(0,8 \mathrm{MD}, 6 \mathrm{MD}+2 \mathrm{C}, 4 \mathrm{MD}+4 \mathrm{C}, 2 \mathrm{MD}+6 \mathrm{C}, 8 \mathrm{C}, 6 \mathrm{MD}+2 \mathrm{RHA}, 4 \mathrm{MD}+4 \mathrm{RHA}$, $2 \mathrm{MD}+6 \mathrm{RHA}, 8 \mathrm{RHA}, 6 \mathrm{RHA}+2 \mathrm{C}, 4 \mathrm{RHA}+4 \mathrm{C}, 2 \mathrm{RHA}+6 \mathrm{C}, 2 \mathrm{MD}+2 \mathrm{RHA}+4 \mathrm{C}, 4 \mathrm{MD}+2 \mathrm{RHA}+2 \mathrm{C}, \quad 2 \mathrm{MD}+4 \mathrm{RHA}+2 \mathrm{C})$ proportion. Then LL, PI, OMC, and CBR decreased as the cement ratio increased, while PL, MDD and CBR value increases instead of MD and RHA increases, however, as MD and RHA increase, the quantity of cement decreases. The laboratory outcome was compared with the requirement of Ethiopian road authority standard, ASTM and AASHTO. Based on this study all mixing stabilizers (MD-cement, RHA-cement, MD-RHA, MD-RHA-cement) and $8 \%$ of RHA and cement fulfill the ERA standard specification requirements for its CBR swell value. However, $8 \%$ of marble dust alone does not fulfill the Ethiopia road authority requirements for CBR swell. The MD and RHA standalone does not improving some of the engineering properties of soil samples used for subgrade construction. However, they mixed with different percentages of cement can effectively stabilizer for this expansive soil for road sub-grade construction.
\end{abstract}

Copyright (C) 2021 UNIMAS Publisher. This is an open access article distributed under the Creative Commons Attribution-Non-commercial-Share Alike 4.0 International License which permits unrestricted use, distribution, and reproduction in any medium, provided the original work is properly cited.

Keywords: Expansive soil, RHA, MD, Cement, Percentage by weight 


\subsection{INTRODUCTION}

One of the major problems worldwide is the availability of natural construction material within reasonable hauling distance from the project to be planned to build; this directly impacts the cost of a project[1]. However, in some parts of the country, the natural resources construction materials do not satisfy the standard specification requirements [2]. Specifically, the main problems associated with construction materials in the road industry was failures of pavement before attain design period of pavement, and the engineering problems related to expansive soils have been reported in many countries, but those mostly located in arid and semi-arid regions[3]. Expansive soils, susceptible to detrimental volumetric changes, with the change in moisture. The cyclic wetting and drying process causes vertical movements in expansive soils and movements to lead to the failure of pavements or structures [4]. Such problems exist widely in Ethiopia. It's estimated that the region covered by expansive soil in Ethiopia is 23.7 million acres [5, 6].Roads constructed on expansive soil also have a problem on structural layers on the embankment due to its unusual cyclic swell shrink behavior of expansive soil. This form of soil swells when it comes into contact with water, and shrinks when the water evaporates. Due to this movement, loosely loaded structures such as foundations, pavements, channels beds and linings and residential buildings constructed on then are seriously damaged $[7,8]$. The annual damage to civil engineering structures on expansive soil has been predicted to be $\$ 1000$ million in the US, $£ 150$ millions in UK and several billions pounds worldwide [9-11]. Road pavements typically consist of many layers of different layer materials during construction of embankments of road, and one of them is sub-grade soil layer. The subbase layer can be either indigenous soil or imported material. Suppose the native soil is found to be unacceptable as a sub-grade soil. In that case, it is typically adequately treated or stabilized and is used to be prevent the high cost that may be incurred for the imported materials and to decide the types of sub-grade soil materials that may be used, types of treatment that may be suitable and a series of soil investigations must be carried out. Usually, subgrade soil stability is expressed in terms of bearing capacity, which is related to the soil basic geotechnical properties [12]. Expansive soil composed of predominately of a specific types of clay soil, is one of the types of foundation soil considered troublesome. This soil swells if its water content rises and shrinks if the water table decreases due to seasonal condition, the fluctuation of moisture content occurs typically. Either vertically or horizontally, the change in the soil volume associated with expansion or shrinkages results in deformation of soil. This deformation will lead to significant distortion of the road surface in the case of pavement. Therefore; stabilization is needed to mitigate these issues [13]. The pavement design assumes that the minimum defined structural quality for each material layer in the paving system will be achieved. Each layer must resist shearing, to avoid excessive deflections causing the layer or overlaying layers to crack fatigue, and to prevent excessive permanent deformation. If the consistency of a soil layer increases, the capacity of that layer to spread the load over a wider area increases, so that it is possible to reduce the necessary thickness of the soil and surface layer [14]. Stabilization by compaction (mechanical) or stabilization by chemical additives are widely used methods of stabilizing soils. Pozzolana is classified as a silica or alumino-siliceous material that chemically reacts at normal room temperature with calcium with calcium hydroxide, released by the hydration of Portland cement, in the finely divided form and moisture presence, to form compounds with Cementitious properties [12]. Materials do not possess cementing properties of their own, but they contain silica and alumina in a reactive method. Forming cementitious property compound, pozzolanic materials chemically react with calcium hydroxide in water [15]. Silica reactions in calcium hydroxide and water to produce calcium silicate hydrates are the pozzolanic reaction (C-S-H). C-S-H provides a denser microstructure that increases resilience, decreases concrete permeability and enhances its chemical attack resistance. By adding pozzolana, pore size and porosity are decreases, leading to increases strength [16]. Road designer tends to reuse an industrial waste material for soil sub-grade stabilization to minimize the cost of sub-grade stabilization and to reduce adverse environmental impact on surrounding. One of them was a marble dust (MD) industrial wastes and rice husk ash (RHA) agricultural wastes material were to be utilized as a stabilizer material for over-all ground improvement purposes. The rice husks are burn-in uncontrolled condition. Marble dust (MD) and Rice husk ash (RHA) are commonly mixed with other stabilizing materials such as cement or lime in stabilized road pavement layers. Because of the cost of high-quality materials required for various geotechnical projects, engineers are trying to improve the physical property of local soils through various method and techniques $[17,18]$.The research's main objective this research study is to increase the expansive soil's strength of sub-grade soil by using the waste MD, RHA, and cement by mixing in appropriate proportion to prepare sub-grade soil construction. 


\subsection{MATERIALS AND METHOD}

\subsection{Materials}

The ingredients utilized in this experiments were expansive soil, MD, RHA and cement. The weak sub-grade soil samples used for this research investigation were collected; Woldia town, Gomata Teachers' Condominium (GTC) and Millennium Secondary School (MSS) as shown in Figure 1. The soil is black in color for both sites, and purposive sampling, which is a nonprobability method, was used to collect the disturbed sample at a depth of $1.5 \mathrm{~m}$ to $2.0 \mathrm{~m}$ in order to avoid organic maters on the top surface of the ground.

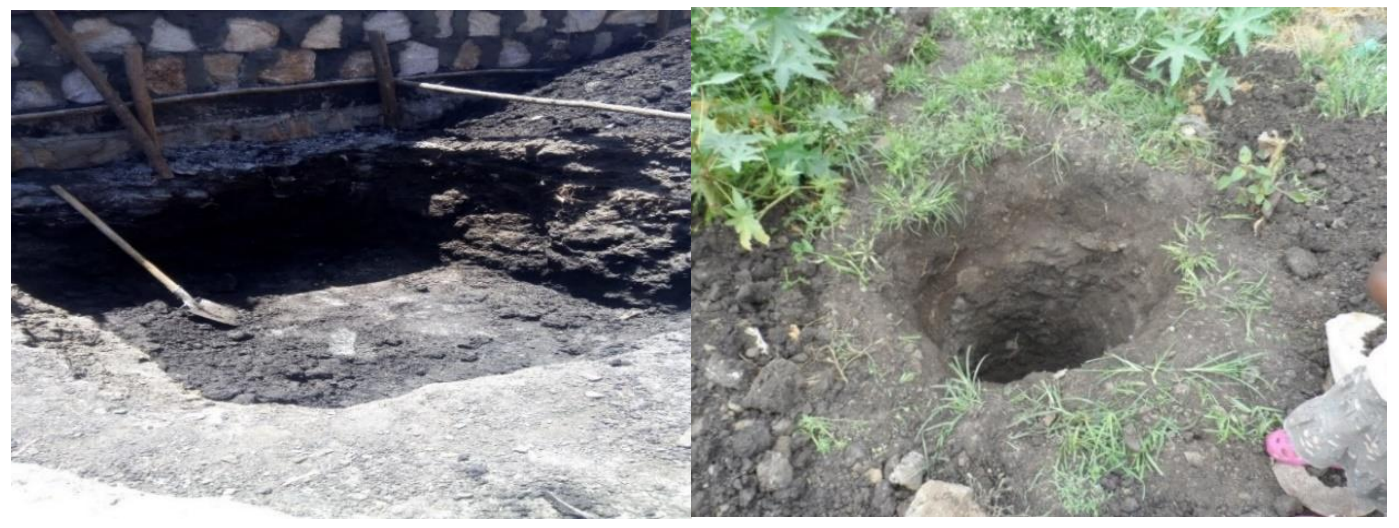

Figure 1 Photos of sample taking at GTC (left) and MSS (right).

Marble dust is obtained from a marble cutting and polishing industry that is locally accessible. The ADEWA mar ble industry is the location of ETHIOPIA's marble industry as shown in Figure 2 during sample collection.
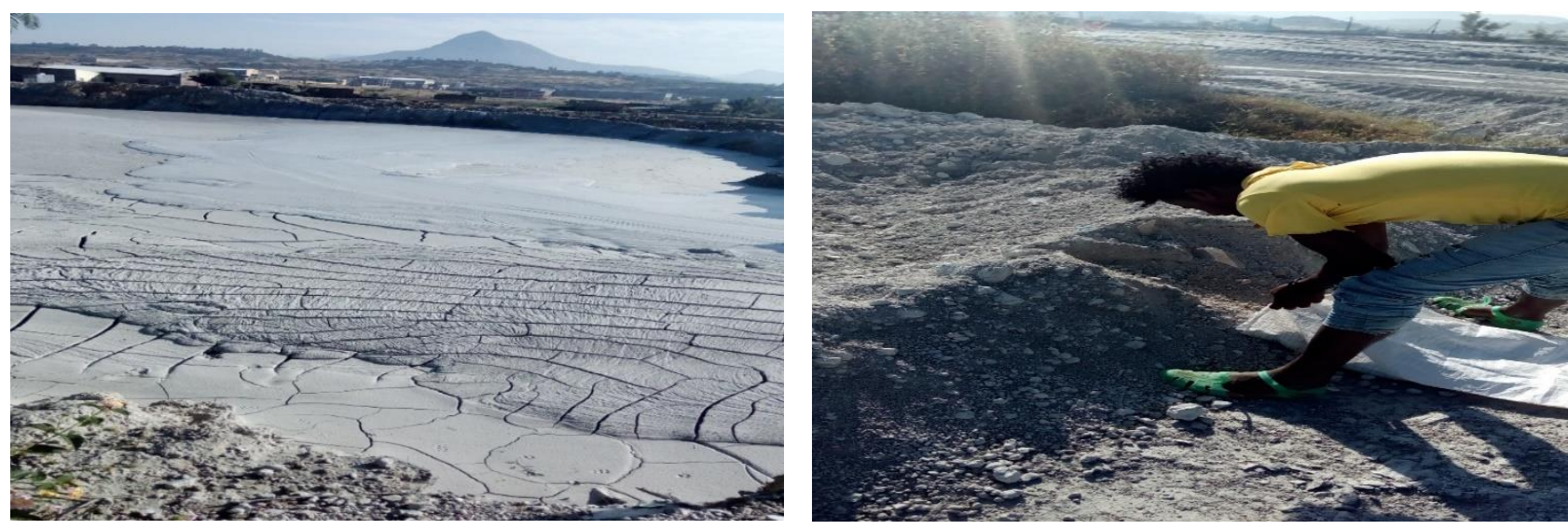

Figure 2 Photos of the process of MD preparation

Portland cement is obtained from a locally available trading market and production industry in MEKELLE. Ordinary Portland cement (OPC) with grade $43 \mathrm{~N}$ was purchased for this research. The uncontrilled burning of the rice husk produces Rice Husk Ash (RHA). Husk is a byproduct of the Amhara region of Ethiopia's rice milling industry were taken for this study. 

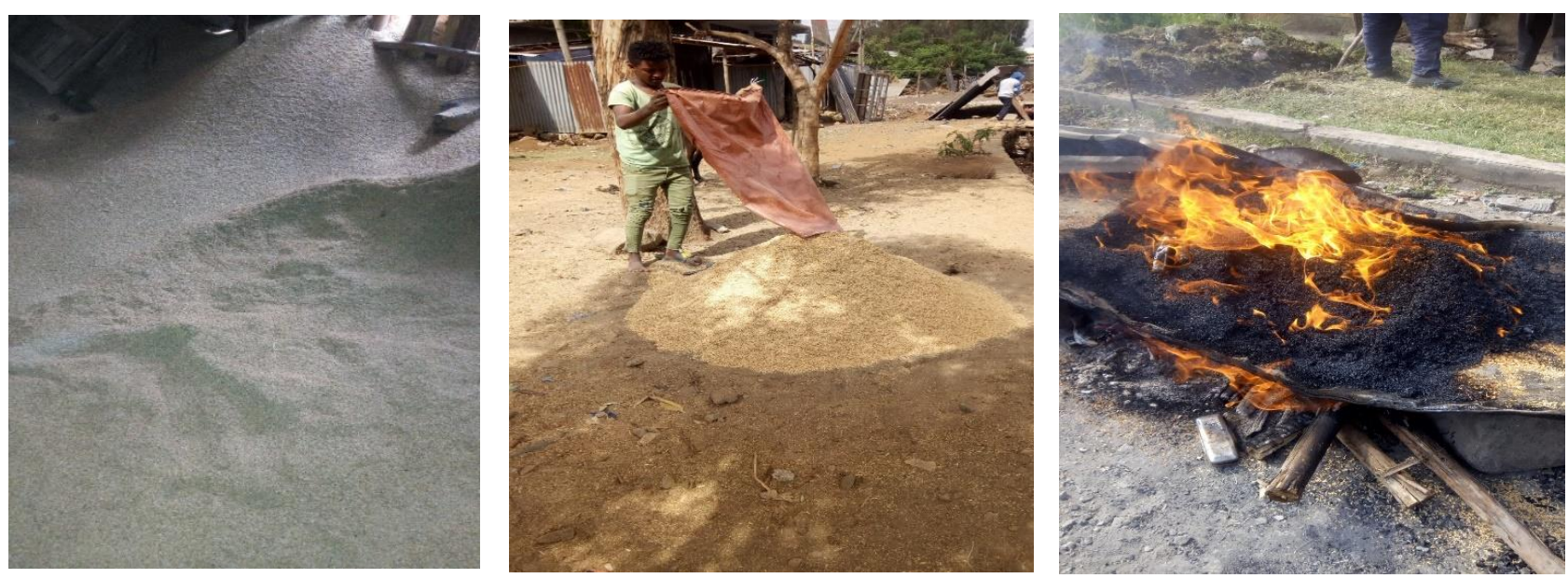

Figure 3 Photos of the process of RHA preparation

\subsection{Study design}

An experimental comparative study design was employed in this study.

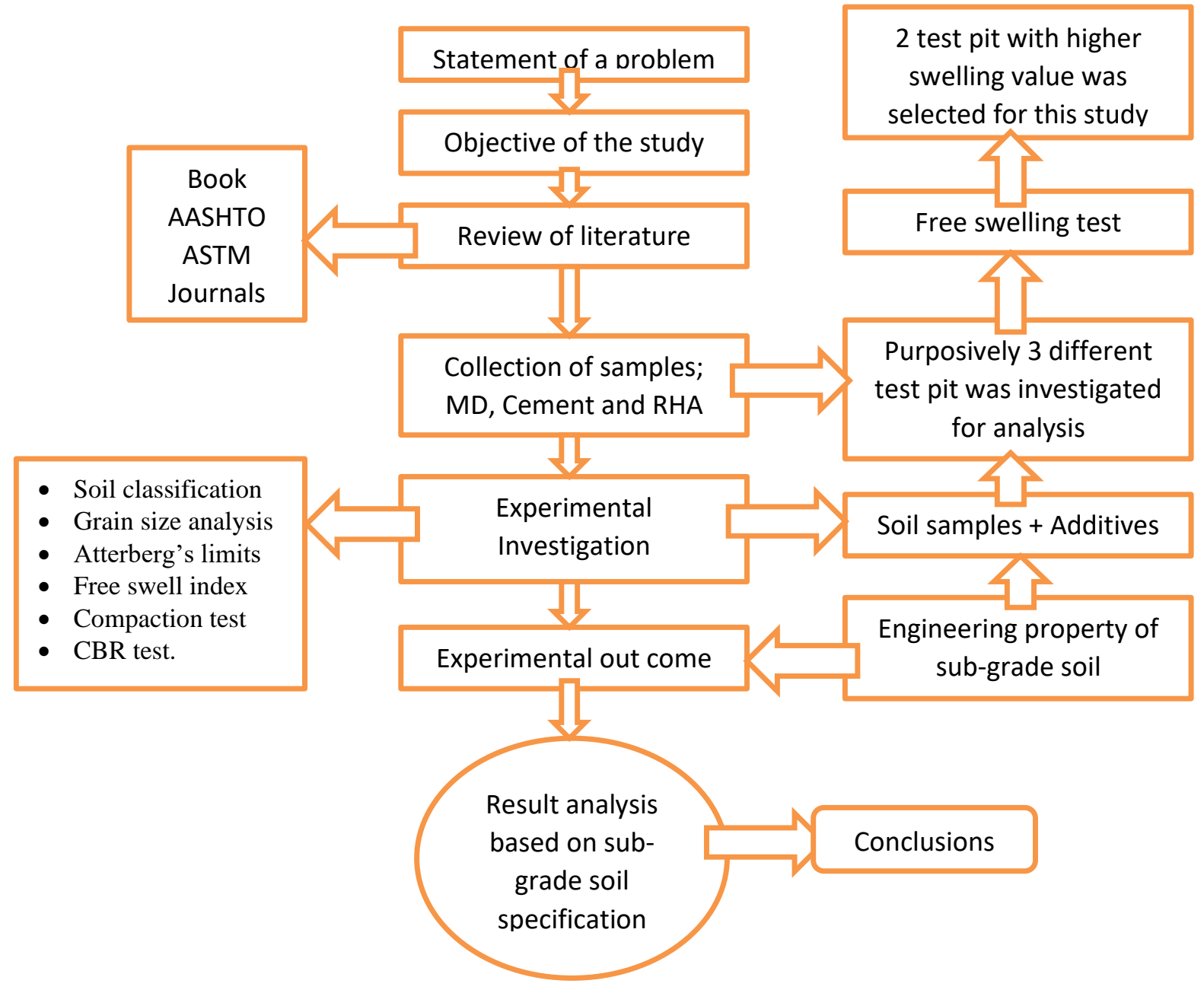

Figure 4 Study design flow chart 
2.3 Methods and standard testing procedure

The standards and specification for this study were adapted from AASHTO and ASTM.

Table 1 Standards and specifications for this study

\begin{tabular}{|c|c|c|c|}
\hline \multirow{2}{*}{ № } & \multirow{2}{*}{ Laboratory tests } & \multicolumn{2}{|c|}{ Standards } \\
\hline & & AASHTO & ASTM \\
\hline 1 & Major and minor Oxides & & C-618 \\
\hline 3 & Moisture content & T-265 & \\
\hline 4 & Grain size analysis & T88 & \\
\hline 5 & Atterberg limits & T089-96 & \\
\hline 6 & Soil classification & M-145 & D2487-98 \\
\hline 7 & Specific gravity & & D854-83 \\
\hline 8 & Standard proctor compaction & T-99 & \\
\hline 9 & CBR & T193-93 & \\
\hline 10 & Hydrometer analysis & & D-422 \\
\hline
\end{tabular}

\subsection{Expansive soil}

\subsubsection{Sample preparation}

Before treating the samples, the soils were classified according to the AASHTO and ASTM soil classification system, the samples air-dried adequately, and the stabilizer mixed with the prepared soil sample.

First step: The air-dried sample mixed with the MD, RHA and cement based on the percent required with the required percent started from $0 \%$ to $8 \%$ within $2 \%$ difference for all additives. The additives were MD, RHA, and cement.

Second step: This properly mixed soil used for Atterberg limit, free swell index, compaction, the Californian bearing ratio by adding water to the properly mixed soil sample by trying blended thoroughly until becomes homogeneous based on the required maximum effect on the desired moisture-density curve.

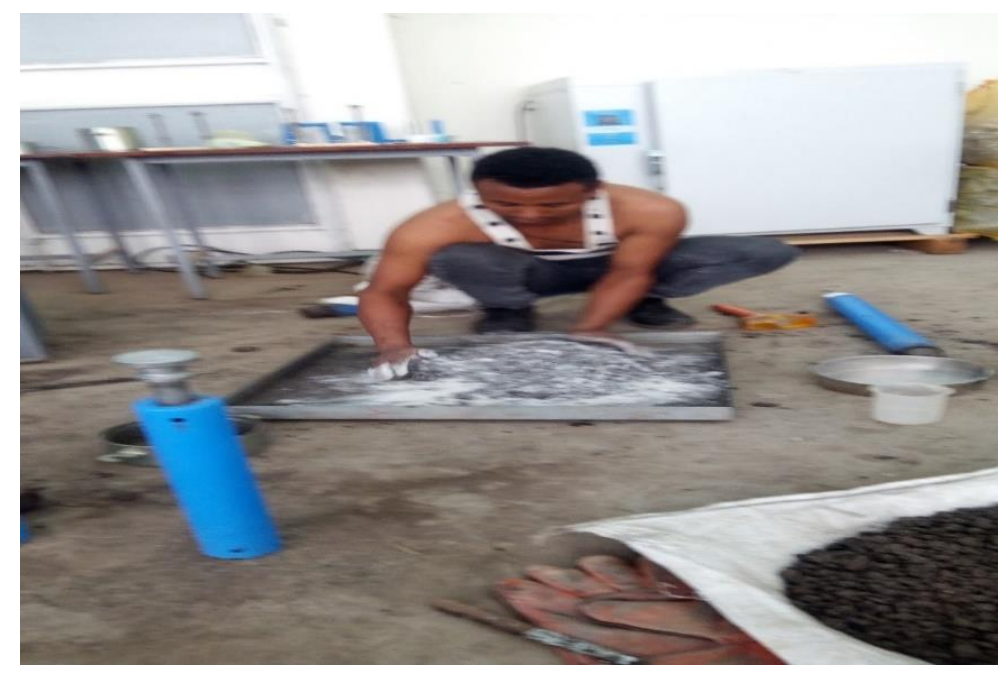

Figure 5 The sample containing mixing of MD, RHA and cement

\subsection{RESULTS AND DISCUSSIONS}

\subsection{Laboratory result for chemical properties of RHA}

The rate of pozzolana reaction depends on the basic characteristics of the pozzolana, such as its density, surface a rea and chemical composition. External factors such as mix proportions, water quantity,reaction temperature, curi ng condition and length can regulate the rate of pozzolanic reaction [16]. 
Table 2 Chemical composition of RHA

\begin{tabular}{|c|c|c|c|}
\hline Chemical composition & Test result, (\%) & ASTM (C618) Requirement in (\%) & Remark \\
\hline Silica $\left(\mathrm{SiO}_{2}\right)$ & 68.2 & 35 Min. & Satisfied \\
\hline Aluminum $\left(\mathrm{AL}_{2} \mathrm{O}_{3}\right)$ & $<0.01$ & & \\
\hline Iron $\left(\mathrm{Fe}_{2} \mathrm{O}_{3}\right)$ & 1.92 & & \\
\hline Calcium $(\mathrm{CaO})$ & $<0.01$ & & Satisfied \\
\hline Magnesium $(\mathrm{MgO})$ & 0.16 & & \\
\hline Sodium $\left(\mathrm{Na}_{2} \mathrm{O}\right)$ & 0.88 & & \\
\hline Potassium $\left(\mathrm{K}_{2} \mathrm{O}\right)$ & 2.32 & & \\
\hline $\mathrm{MnO}$ & 0.12 & & \\
\hline $\mathrm{P}_{2} \mathrm{O}_{5}$ & 0.57 & & \\
\hline $\mathrm{TiO}_{2}$ & $<0.01$ & & \\
\hline $\mathrm{H} 2 \mathrm{O}$ & 4.45 & & Satisfied \\
\hline $\mathrm{LOI}$ & 23.65 & & \\
\hline $\mathrm{SiO} 2+\mathrm{Al} 2 \mathrm{O} 3+\mathrm{Fe} 2 \mathrm{O} 3$ & 70.13 & & \\
\hline
\end{tabular}

Table 3 Chemical composition of MD

\begin{tabular}{|c|c|c|c|}
\hline Chemical composition & Test result, (\%) & ASTM (C618) Requirement in (\%) & Remark \\
\hline Silica $\left(\mathrm{SiO}_{2}\right)$ & 37.16 & $35 \mathrm{Min}$. & Satisfied \\
\hline Aluminum $\left(\mathrm{AL}_{2} \mathrm{O}_{3}\right)$ & 5.27 & & \\
\hline Iron $\left(\mathrm{Fe}_{2} \mathrm{O}_{3}\right)$ & 1.66 & & \\
\hline Calcium $(\mathrm{CaO})$ & 26.40 & & \\
\hline Magnesium $(\mathrm{MgO})$ & 1.66 & & Satisfied \\
\hline Sodium $\left(\mathrm{Na}_{2} \mathrm{O}\right)$ & 2.22 & & \\
\hline Potassium $\left(\mathrm{K}_{2} \mathrm{O}\right)$ & 1.76 & & \\
\hline $\mathrm{MnO}$ & 0.06 & & \\
\hline $\mathrm{P}_{2} \mathrm{O}_{5}$ & 0.1 & & \\
\hline $\mathrm{TiO}_{2}$ & 0.12 & & \\
\hline $\mathrm{H}_{2} \mathrm{O}$ & 0.82 & & \\
\hline $\mathrm{LOI}$ & 21.84 & & Un satisfied \\
\hline $\mathrm{SiO} 2+\mathrm{Al2O} 3+\mathrm{Fe} 2 \mathrm{O} 3$ & 42.43166 & & \\
\hline
\end{tabular}

Based on Table 2 and Table 3, all chemical properties of used for this study such as RHA and MD are with an acceptable range of ASTM C618 except $\mathrm{SiO}_{2}+\mathrm{Al}_{2} \mathrm{O}_{3}+\mathrm{Fe}_{2} \mathrm{O}_{3}$ for marble dust. As test result indicates, the combined percent composition of main oxides $\left(\mathrm{SiO}_{2}, \mathrm{Al}_{2} \mathrm{O}_{3}, \mathrm{Fe}_{2} \mathrm{O}_{3}\right)$ was $70.13 \%$ for rice husk ash $42.43 \%$ for marble dust (MD), and the mixture of rice husk ash and marble dust have $111.56 \%$ which is above the minimum of 70\% of specified by ASTM (C618) which is acceptable as a good Pozzolana properties by having a cementitious nature properties in terms to its physical and chemical compositions that satisfied a minimum requirement stated standard specification.

3.2 Geotechnical properties of soil sample

Table 4 Geotechnical properties of soil samples

\begin{tabular}{|l|c|c|}
\hline \multirow{2}{*}{ Parameters } & \multicolumn{2}{|c|}{ Result } \\
\cline { 2 - 3 } & GTC & MSS \\
\hline Natural moisture content, $\%$ & 25.265 & 25.195 \\
\hline Percentage passing through No 200 sieve & 97.94 & 97.86 \\
\hline liquid limit (LL), $\%$ & 73.4 & 79.70 \\
\hline Plastic limit (PL), $\%$ & 30.68 & 30.91 \\
\hline Plasticity index (PI), $\%$ & 42.72 & 48.79 \\
\hline AASHTO & $\mathrm{A}-7-5$ & $\mathrm{~A}-7-5$ \\
\hline USCS & $\mathrm{CH}$ & $\mathrm{CH}$ \\
\hline Specific gravity & 2.71 & 2.87 \\
\hline Free swell index, $\%$ & 85 & 87 \\
\hline Maximum dry density, g/cm & \\
\hline Optimum moisture content (OMC), $\%$ & 1.30 & 1.24 \\
\hline
\end{tabular}




\begin{tabular}{|l|c|c|}
\hline Soaked CBR value, $\%$ & 2.265 & 2.121 \\
\hline CBR swell, $\%$ & 4.29 & 4.90 \\
\hline Color & Black & Black \\
\hline
\end{tabular}

In general, low plasticity is in between $35 \%$ and $50 \%$, intermediate plasticity is between $50 \%$ and $70 \%$, while high Plasticity value between $70 \%$ and $90 \%$ also its liquid limit a maximum value less than 35\% [19]. Therefore based on above value soil samples property indicates that very high plasticity clay.

\subsubsection{Particle size distribution of GTC and MSS}

The soil sample GTC is dark, and almost $97.94 \%$ of the soil passes through № 200 sieve analysis as shown on Grain size distribution curve.

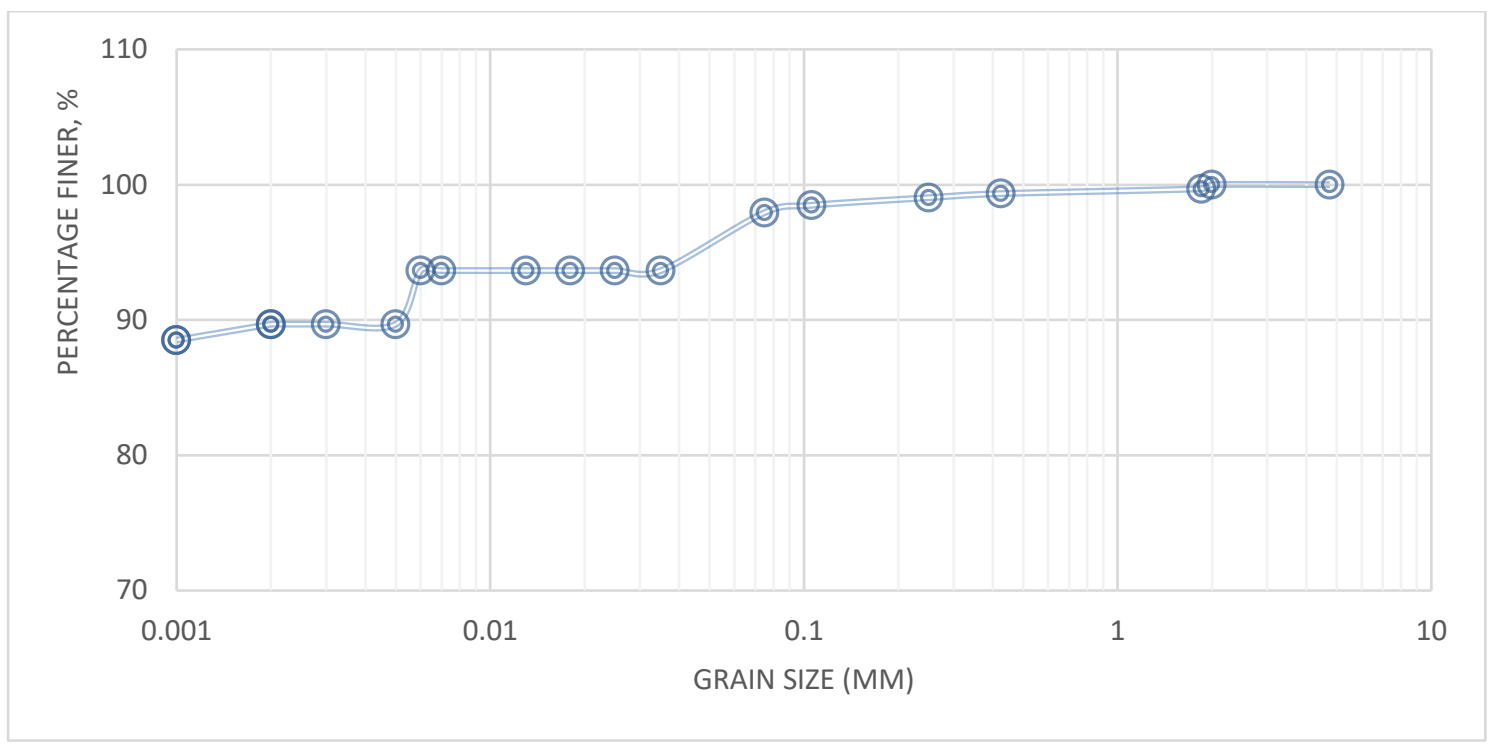

Figure 6 Grain size distribution curve of GTC soil sample

The soil for sample MSS is black, and almost $97.86 \%$ of the soil passing through sieve № 200 analysis as shown on Grain size distribution curve.

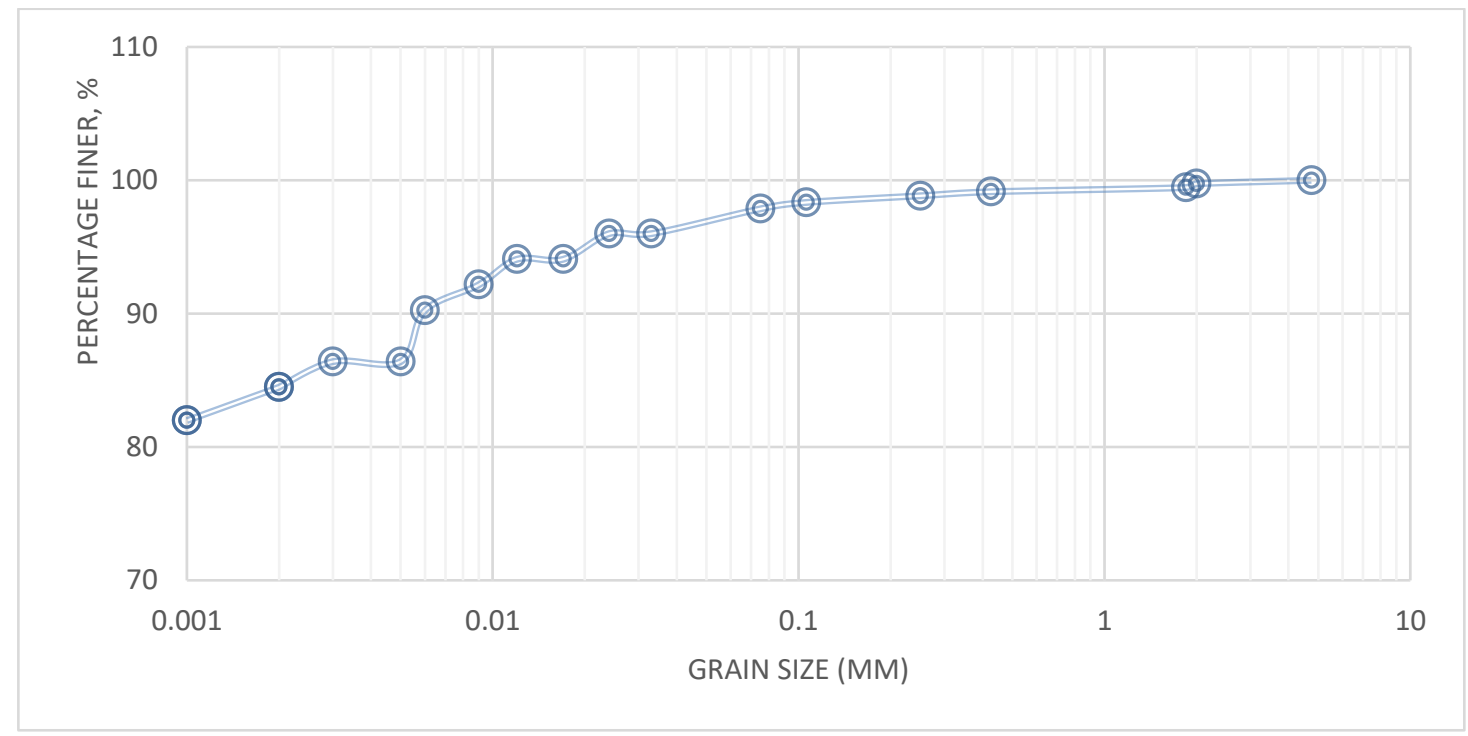

Figure 7 Grain size distribution curve of MSS soil sample 
Based on the unified soil classification system (USCS), the soils 50\% minimum pass through sieve № 200 are classified as fine-grained soil (i.e., silt and clay soil), and the minimum percentage pass through sieve № 200 for the soil understudy is $97.94 \%$ and $97.86 \%$ and the soil categorized as fine-grained soil.

\subsubsection{Atterberg test results}

Atterberg limits (liquid limit and plastic limit) were determined according to AASHTO T-89 and AASHTO T-90, respectively.

Table 5 Atterberg test results of GTC and MSS sample soil

\begin{tabular}{|l|l|l|l|}
\hline \multicolumn{3}{|c|}{$\mathbf{1 0 0 \%}$ natural soil } & \\
\hline Sample name & Liquid limit (\%) & Plastic limit (\%) & Plasticity index (PI) \\
\hline GTC & 73.40 & 30.68 & 42.72 \\
\hline MSS & 79.70 & 30.93 & 48.79 \\
\hline
\end{tabular}

\subsubsection{Soil Classification}

Laboratory test result indicates based on AASHTO and USCS Soil classification system for GTC and MSS soil sample illustrated as in Table 6.

Table 6 Soil classification according to AASHTO and USCS for both soil sample

\begin{tabular}{|c|c|c|c|c|c|c|}
\hline Sample & $\begin{array}{c}\text { Liquid } \\
\text { limit \% }\end{array}$ & $\begin{array}{c}\text { Plastic } \\
\text { limit \% }\end{array}$ & $\begin{array}{c}\text { Plastic } \\
\text { index }\end{array}$ & $\begin{array}{c}\text { Group } \\
\text { index }\end{array}$ & AASHTO & USCS \\
\hline GTC & 73.40 & 30.68 & 42.72 & 50 & $\mathrm{~A}-7-5$ & $\mathrm{CH}$ \\
\hline MSS & 79.70 & 30.91 & 48.79 & 57 & $\mathrm{~A}-7-5$ & $\mathrm{CH}$ \\
\hline
\end{tabular}

\subsubsection{Specific gravity for subgrade soil}

Specific gravity which is the measuring of the heaviness of soil particle is determined by the method of pycnometer method using the soil sample passing sieve number 10 and oven dried at $105^{\circ} \mathrm{c}$. The test includes the determination the specific gravity for the natural soil. The test was conducted in accordance with ASTM-854 testing procedure. Table 7 shows the Specific gravity of natural sub-grade soil.

Table 7 Specific gravity for natural sub-grade soil

\begin{tabular}{|c|c|c|}
\hline Soil sample & GTC & MSS \\
\hline Specific gravity & 2.71 & 2.87 \\
\hline
\end{tabular}

\subsubsection{Free swell index}

The free swell test value of for sample GTC and MSS indicates that $85 \%$ and $87 \%$ respectively. Soils having the free swell value above $100 \%$ can cause damage whereas free swell as low as $100 \%$ can cause considerable damage to light loaded structures and soils having a free swell value less than 50\% seldom exhibits appreciable volume change even under light loads. Hence the free swell value of the soil under study exceeds $50 \%$ such soils undergo volumetric changes loading to pavement distortion, cracking and general unevenness due to seasonal wetting and drying.

Table 8 Free swell index test results for natural subgrade soil sample

\begin{tabular}{|c|c|}
\hline Sample Name & Free swell index (\%) \\
\hline GTC & 85 \\
\hline MSS & 87 \\
\hline
\end{tabular}

\subsubsection{Compaction test results of expansive sub-grade soil samples (AASHTO T-99)}

The Standard proctor test was done to determine the maximum dry density (MDD) and optimum moisture content (OMC) natural subgrade soil according to AASHTO T-99. Prepared a sufficient quantity of air dry soil were passing 
through sieve number $4(4.75 \mathrm{~mm})$ and measured $3000 \mathrm{gm}$ of soil sample and compact in three layers for each proctor compaction test. The GTC soil sample has optimum moisture content $38 \%$ and maximum dry density $1.30 \mathrm{gm} / \mathrm{cm}^{3}$. Also, MSS soil sample has optimum moisture content $38.89 \%$ and maximum dry density $1.223 \mathrm{gm} / \mathrm{cm}^{3}$ as shown below Figure 8 .

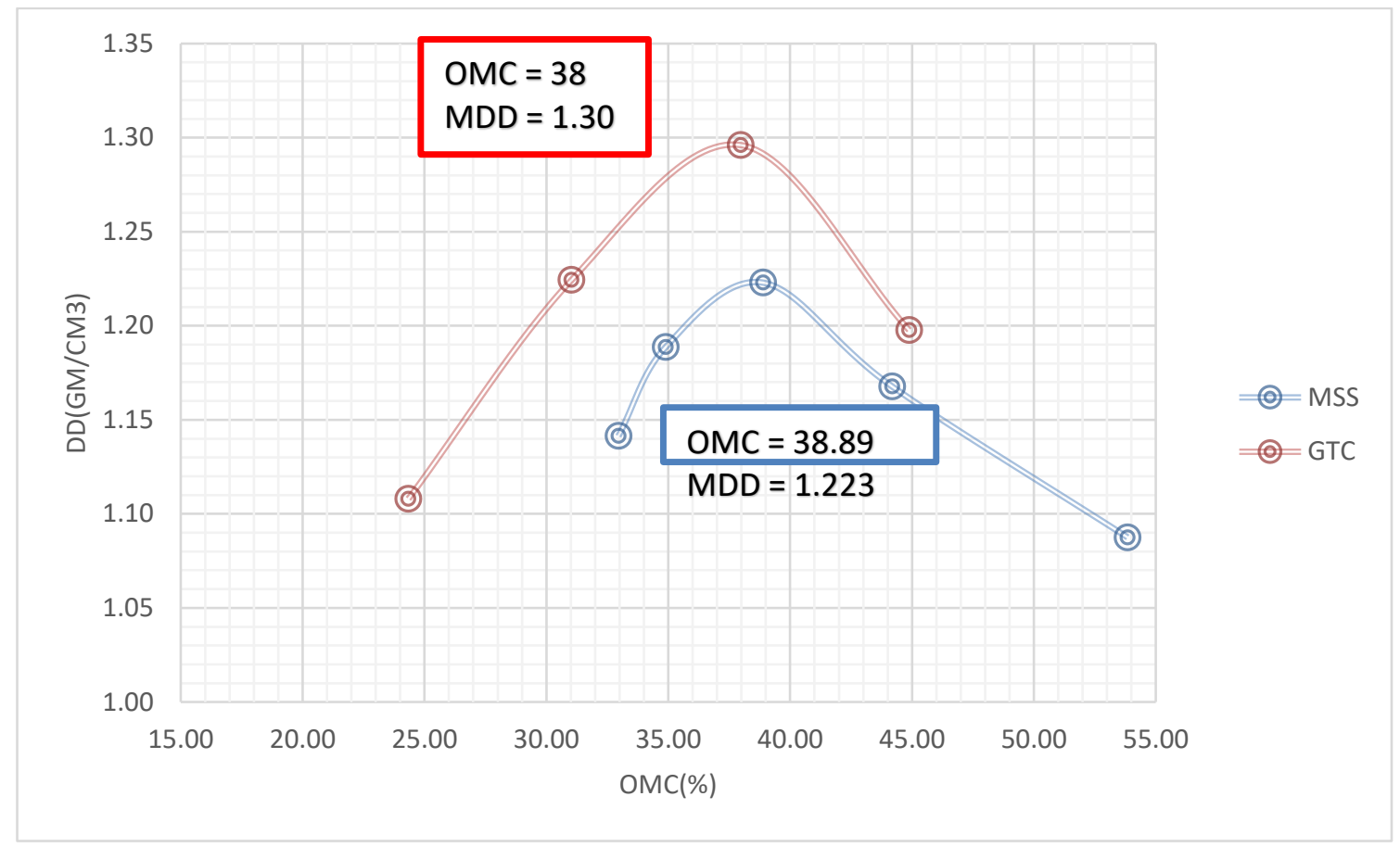

Figure 8 Moisture density relation for natural sub-grade soil

3.2.7 CBR test results for natural sub-grade soil (AASHTO T-193)

Table 9 CBR test results of expansive soils

\begin{tabular}{|c|c|c|c|c|c|c|}
\hline \multirow{2}{*}{ Sample } & \multirow{2}{*}{$\begin{array}{c}\text { Number } \\
\text { of belows }\end{array}$} & \multicolumn{2}{|c|}{ Load (KN) } & \multicolumn{2}{|c|}{ CBR (\%) } & \multirow{2}{*}{ Swell in (\%) } \\
\cline { 3 - 6 } & $\mathbf{2 . 5 m m}$ & $\mathbf{5 . 0 m m}$ & $\mathbf{2 . 5 m m}$ & $\mathbf{5 . 0 m m}$ & \\
\hline GTC & 56 & 0.299 & 0.381 & 2.265 & 1.93 & 4.29 \\
\hline MSS & 56 & 0.280 & 0.36 & 2.121 & 1.80 & 4.90 \\
\hline
\end{tabular}

The GTC soil sample had 2.265\% soaked CBR value with 4.29\% CBR swells, and the MSS soil sample had $2.121 \%$ soaked CBR value with $4.90 \%$ its swell, according to the laboratory test result in Table 9 . The socked CBR test showed that, as compared to the Ethiopian Roads Authority Manual 2013 for both sub-grade soil has lower CBR value and it does not meet the minimum requirements as sub-grade material. The CBR swell value are also above the specified maximum value of $2 \%$; therefore this soil must be stabilized before utilization.

\subsection{Overall Characterization of the natural sub-grade soil}

According to the laboratory test results of the natural sub-grade soil sample obtained during the present study, the proportion of fines passing no 200 sieves are $97.94 \%$ and $97.86 \%$, liquid limit $73.40 \%$ and $79.70 \%$, and plasticity index $42.72 \%$ and $48.79 \%$, for GTC and MSS soil sample respectively, Both soils samples are classified into A-75 as per the AASHTO and $\mathrm{CH}$ as per the USCS classification system. As far as the engineering efficiency of soils of this class is concerned, such soils are expansive soils that have high volume changing properties with moisture content variation [20]. The liquid limit and plastic index values are far higher than the Ethiopian road authority standard requirement; i.e. less than $60 \%$ liquid limit and less than $30 \%$ plasticity index. Therefore, soil samples show an expansive property. The $85 \%$ free swell index and $87 \%$ for GTCand MSS soil samples, respectively, have indicated that the soils are expansive soil because their free swell index is greater than 50\%. In addition, the CBR value and free swell index test value shows that $2.265 \%, 2.121 \%$ and $4.29 \%$, respectively, $4.90 \%$ for GTC and MSS soil samples. This shows 
that when compared to Ethiopian road authority requirements of the CBR value more than 5\% and percent of swell was less than $2 \%$, so that this soils have a low load-bearing capacity and high swelling potential, which renders it unsuitable for construction without any suitable treatment techniques. However, the above comparisons between the design manual of Ethiopian road authority and the soil laboratory findings indicates that the soil samples does not entirely meet the criteria as sub-grade soil and is considered inadequate for subgrades in road construction. Therefore, prior to use as a road sub-grade soil; it should be treated with a suitable improvement methods.

\subsection{Laboratory test results of stabilization of expansive soil}

\subsubsection{Atterberg limits.}

One of the important and the principal aims of presented this study was to evaluate the changes of liquid limits, plastic limits and plasticity index with additions of marble dust, rice husk ash and cement to selected soil sample. To achieve this objective, liquid limit and plastic limit tests were conducted on marble dust, rice husk ash and cement-soil mixtures according to the consistency tests of AASHTO T-89 and AASHTO T-90 respectively.

Table 10 Atterberg limit test results of MD-RHA-cement to stabilize weak subgrade soils

\begin{tabular}{|c|c|c|c|c|c|c|c|c|}
\hline \multirow{2}{*}{$\begin{array}{l}\text { Sample } \\
\text { name }\end{array}$} & \multicolumn{3}{|c|}{$\begin{array}{l}\text { Mix proportion of MD, RHA and } \\
\text { Cement }\end{array}$} & \multirow{2}{*}{ LL, \% } & \multirow{2}{*}{ PL,\% } & \multirow{2}{*}{ PI,\% } & \multirow{2}{*}{$\begin{array}{l}\text { Ethiopian road } \\
\text { authority manual } \\
(2013) \\
\text { Requirement of PI } \\
\text { in \% }\end{array}$} & \multirow{2}{*}{ Remark } \\
\hline & MD, \% & RHA, \% & Cement, \% & & & & & \\
\hline \multirow{17}{*}{ GTC } & 0 & 0 & 0 & 73.40 & 30.68 & 42.72 & \multirow{17}{*}{$<30$} & Poor \\
\hline & 8 & 0 & 0 & 63.38 & 42.76 & 20.62 & & Satisfied \\
\hline & 6 & 0 & 2 & 62.38 & 46.97 & 15.41 & & Satisfied \\
\hline & 4 & 0 & 4 & 58.73 & 47.27 & 11.46 & & Satisfied \\
\hline & 2 & 0 & 6 & 58.05 & 50.70 & 7.35 & & Satisfied \\
\hline & 0 & 0 & 8 & 56.97 & 52.35 & 4.62 & & Satisfied \\
\hline & 6 & 2 & 0 & 63.12 & 46.86 & 16.26 & & Satisfied \\
\hline & 4 & 4 & 0 & 65.15 & 48.13 & 17.02 & & Satisfied \\
\hline & 2 & 6 & 0 & 68.71 & 51.26 & 17.45 & & Satisfied \\
\hline & 0 & 8 & 0 & 73.09 & 51.58 & 21.51 & & Satisfied \\
\hline & 0 & 6 & 2 & 65.50 & 49.19 & 16.31 & & Satisfied \\
\hline & 0 & 4 & 4 & 64.73 & 50.50 & 14.23 & & Satisfied \\
\hline & 0 & 2 & 6 & 64.17 & 51.77 & 12.40 & & Satisfied \\
\hline & 0 & 0 & 8 & 56.97 & 52.35 & 4.62 & & Satisfied \\
\hline & 2 & 2 & 4 & 58.92 & 49.51 & 9.41 & & Satisfied \\
\hline & 4 & 2 & 2 & 65.94 & 53.26 & 12.68 & & Satisfied \\
\hline & 2 & 4 & 2 & 66.00 & 45.61 & 20.43 & & Satisfied \\
\hline \multirow{14}{*}{ MSS } & 0 & 0 & 0 & 79.70 & 30.91 & 48.79 & \multirow{14}{*}{$<30$} & Poor \\
\hline & 8 & 0 & 0 & 65.11 & 43.33 & 21.78 & & Satisfied \\
\hline & 6 & 0 & 2 & 59.50 & 45.82 & 13.68 & & Satisfied \\
\hline & 4 & 0 & 4 & 58.33 & 48.07 & 10.26 & & Satisfied \\
\hline & 2 & 0 & 6 & 57.56 & 49.08 & 8.48 & & Satisfied \\
\hline & 0 & 0 & 8 & 56.51 & 50.36 & 6.15 & & Satisfied \\
\hline & 6 & 2 & 0 & 66.45 & 51.63 & 14.82 & & Satisfied \\
\hline & 4 & 4 & 0 & 67.50 & 52.17 & 15.33 & & Satisfied \\
\hline & 2 & 6 & 0 & 68.07 & 52.50 & 15.57 & & Satisfied \\
\hline & 0 & 8 & 0 & 70.00 & 53.57 & 16.43 & & Satisfied \\
\hline & 0 & 6 & 2 & 62.11 & 46.91 & 15.20 & & Satisfied \\
\hline & 0 & 4 & 4 & 60.09 & 47.35 & 12.74 & & Satisfied \\
\hline & 0 & 2 & 6 & 58.27 & 47.49 & 10.78 & & Satisfied \\
\hline & 0 & 0 & 8 & 56.51 & 50.36 & 6.15 & & Satisfied \\
\hline
\end{tabular}




\begin{tabular}{|l|l|l|l|l|l|l|l|l|}
\hline \multirow{3}{*}{} & 2 & 2 & 4 & 59.34 & 47.37 & 11.95 & & Satisfied \\
\cline { 2 - 6 } & 4 & 2 & 2 & 60.00 & 46.76 & 14.10 & Satisfied \\
\cline { 2 - 6 } & 2 & 4 & 2 & 65.96 & 51.19 & 14.77 & Satisfied \\
\hline
\end{tabular}

According to the laboratory test results the behavior of the soil sample was changed from highly plasticity soil to low plasticity soil. As the result when the percentage of cement increased plasticity index of the treated soil sample are significantly decrease. Whereas it becomes increase when the percentage of MD and RHA increase, this is the reason because of the content of calcium ions in the MD and RHA not enough for replacement of sodium ions in the soil particle, therefore it is necessary to certain amount of calcium ion from cement till replace the sodium ion.

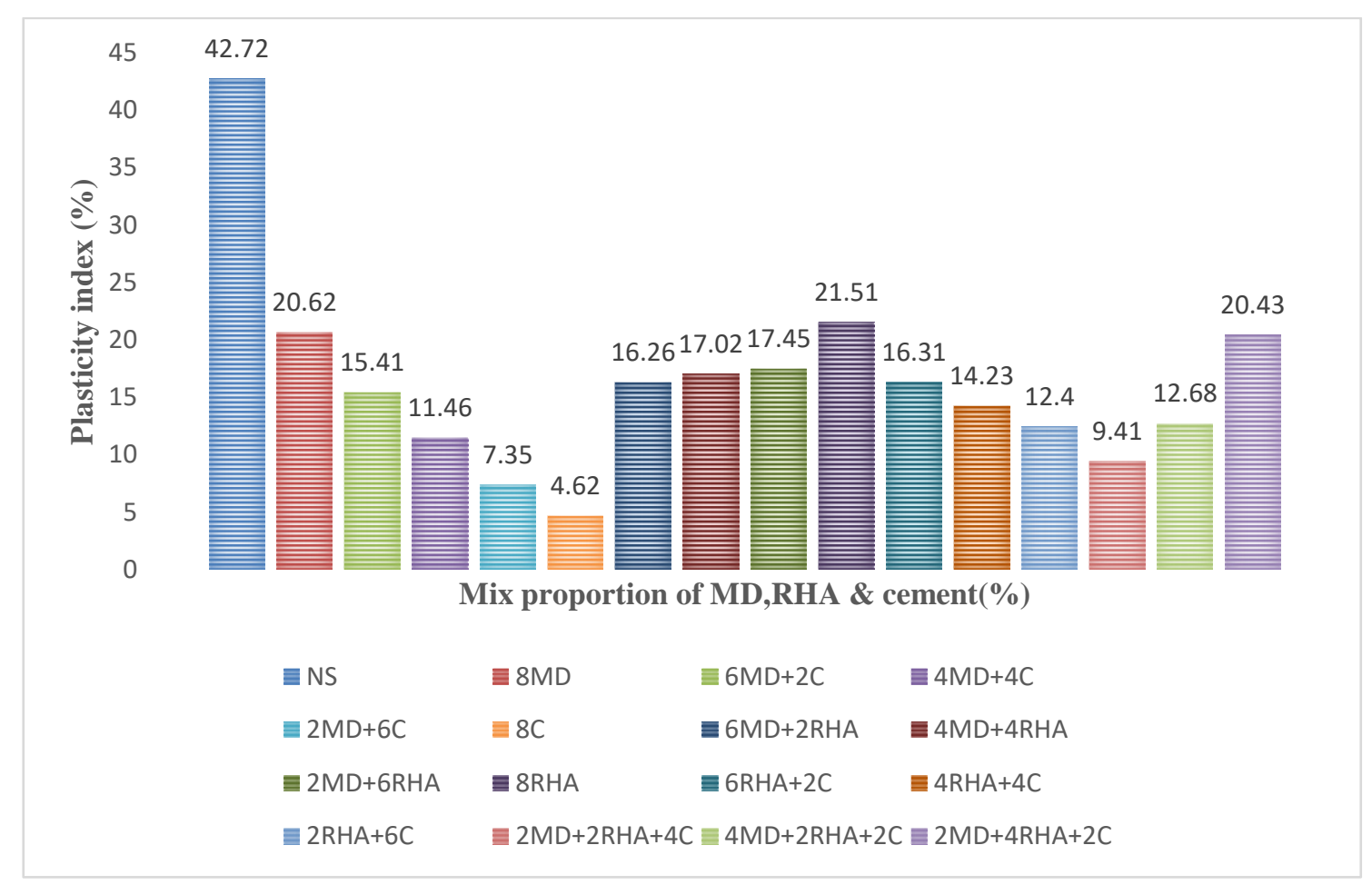

Figure 9 Plasticity index chart for stabilizing GTC soil sample

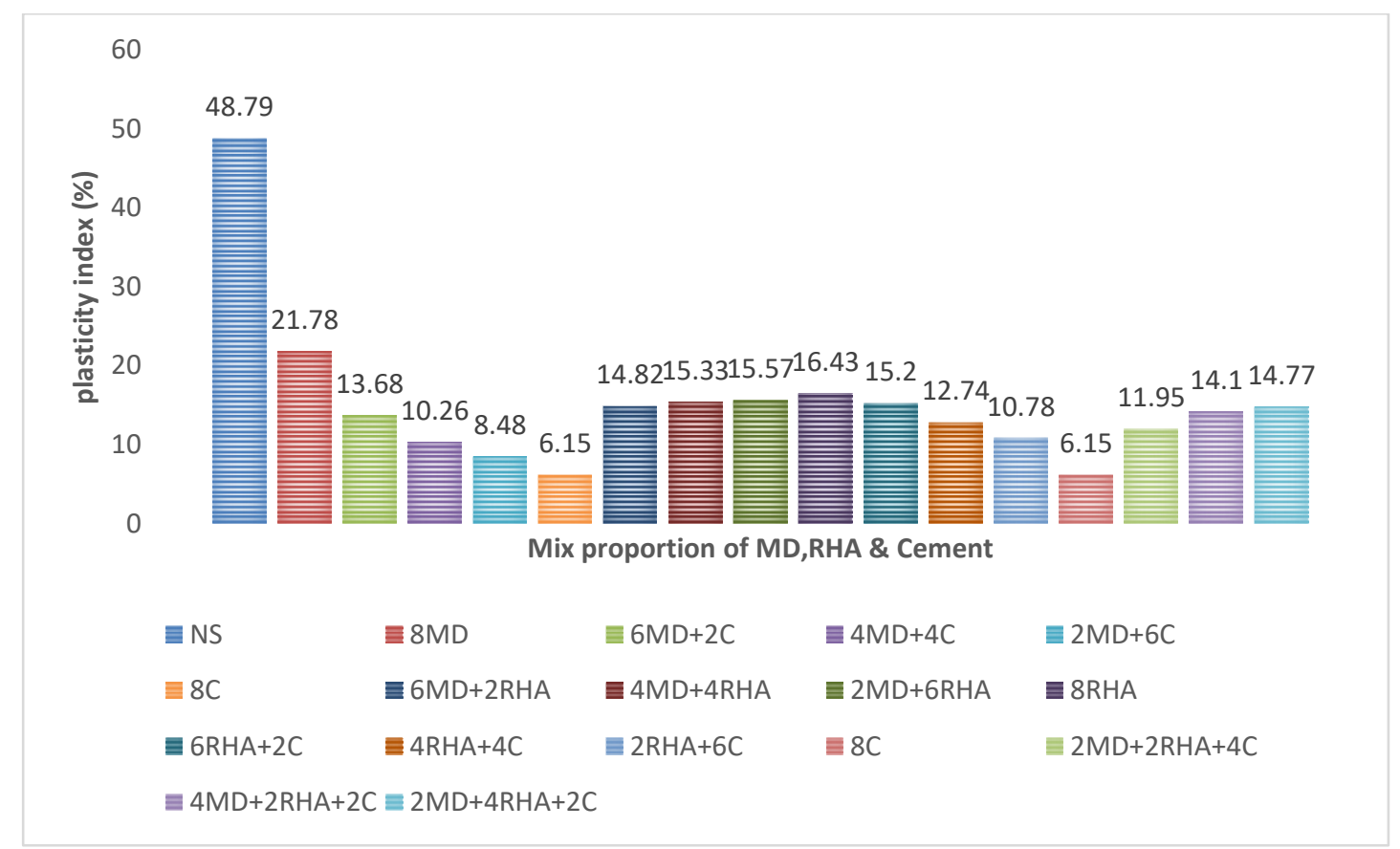

Figure 10 Plasticity index chart for stabilizing MSS soil sample 


\subsubsection{Compaction characteristics of treated soil}

The proctor compaction test was carried out according to AASTHO T-99. The moisture density relations are determined based on AASTHTO T-99. Tests were conducted with different percentages of additives. The percentages of additives shown below at Table 11. The Moisture content versus dry density graph is plotted in Figure 11 and the optimum Moisture Content (OMC) and Maximum Dry Density (MDD) are determined from this graph. The Summarized test results are tabulated in detail as shown Table 11 below.

Table 11 Moisture density relation test results of the mix-ratio of MD, RHA and Cement

\begin{tabular}{|c|c|c|c|c|c|c|c|}
\hline \multirow[t]{2}{*}{$\begin{array}{c}\text { Sample } \\
\text { Name }\end{array}$} & \multicolumn{3}{|c|}{$\begin{array}{c}\text { Mix proportion of MD, RHA and } \\
\text { Cement }\end{array}$} & \multirow[t]{2}{*}{$\begin{array}{c}\text { MDD } \\
\left(\mathrm{g} / \mathrm{cm}^{3}\right)\end{array}$} & \multirow[t]{2}{*}{$\begin{array}{c}\text { \% decrease/ } \\
\text { Increase }\end{array}$} & \multirow[t]{2}{*}{$\begin{array}{c}\text { OMC } \\
(\%)\end{array}$} & \multirow[t]{2}{*}{$\begin{array}{c}\text { \% decrease } \\
\text { increase }\end{array}$} \\
\hline & MD, \% & RHA, \% & Cement, \% & & & & \\
\hline \multirow{17}{*}{ GTC } & 0 & 0 & 0 & 1.296 & & 38 & \\
\hline & 8 & 0 & 0 & 1.403 & 8.26 & 32.5 & -14.47 \\
\hline & 6 & 0 & 2 & 1.386 & 6.94 & 31.02 & -18.37 \\
\hline & 4 & 0 & 4 & 1.336 & 3.09 & 30.51 & -19.71 \\
\hline & 2 & 0 & 6 & 1.379 & 6.40 & 31.33 & -17.55 \\
\hline & 0 & 0 & 8 & 1.390 & 7.25 & 30.86 & -18.79 \\
\hline & 6 & 2 & 0 & 1.383 & 6.71 & 27.54 & -27.53 \\
\hline & 4 & 4 & 0 & 1.307 & 0.85 & 32.32 & -14.95 \\
\hline & 2 & 6 & 0 & 1.291 & -0.39 & 34.05 & -10.39 \\
\hline & 0 & 8 & 0 & 1.165 & -10.11 & 45 & 18.42 \\
\hline & 0 & 6 & 2 & 1.310 & 1.08 & 36 & -5.26 \\
\hline & 0 & 4 & 4 & 1.314 & 1.39 & 37.5 & -1.32 \\
\hline & 0 & 2 & 6 & 1.236 & -4.63 & 35.94 & -5.42 \\
\hline & 0 & 0 & 8 & 1.390 & 7.25 & 30.86 & -18.79 \\
\hline & 2 & 2 & 4 & 1.380 & 6.48 & 30 & -21.05 \\
\hline & 4 & 2 & 2 & 1.403 & 8.26 & 29.63 & -22.03 \\
\hline & 2 & 4 & 2 & 1.314 & 1.39 & 37.5 & -1.32 \\
\hline \multirow{17}{*}{ MSS } & 0 & 0 & 0 & 1.223 & & 38.89 & \\
\hline & 8 & 0 & 0 & 1.367 & 11.77 & 33.33 & -14.30 \\
\hline & 6 & 0 & 2 & 1.370 & 12.02 & 31.02 & -20.24 \\
\hline & 4 & 0 & 4 & 1.319 & 7.85 & 32.28 & -17.00 \\
\hline & 2 & 0 & 6 & 1.331 & 8.83 & 33.13 & -14.81 \\
\hline & 0 & 0 & 8 & 1.353 & 10.63 & 31.51 & -18.98 \\
\hline & 6 & 2 & 0 & 1.363 & 11.45 & 30.18 & -22.40 \\
\hline & 4 & 4 & 0 & 1.313 & 7.36 & 33.58 & -13.65 \\
\hline & 2 & 6 & 0 & 1.267 & 3.60 & 35.22 & -9.44 \\
\hline & 0 & 8 & 0 & 1.307 & 6.87 & 32.46 & -16.53 \\
\hline & 0 & 6 & 2 & 1.300 & 6.30 & 35 & -10.00 \\
\hline & 0 & 4 & 4 & 1.330 & 8.75 & 35.8 & -7.95 \\
\hline & 0 & 2 & 6 & 1.287 & 5.23 & 36.11 & -7.15 \\
\hline & 0 & 0 & 8 & 1.353 & 10.63 & 31.51 & -18.98 \\
\hline & 2 & 2 & 4 & 1.364 & 11.53 & 34.48 & -11.34 \\
\hline & 4 & 2 & 2 & 1.313 & 7.36 & 32.56 & -16.28 \\
\hline & 2 & 4 & 2 & 1.345 & 9.98 & 34.35 & -11.67 \\
\hline
\end{tabular}

As observed in Table 11 above, the MDD of untreated soil samples was observed to be $1.296 \mathrm{~g} / \mathrm{cm}^{3}$ and $1.223 \mathrm{~g} / \mathrm{cm}^{3}$ for GTC and MSS soil samples, respectively. Even though the compaction curve is normal, the curve shifted the left upward in treating the soil with the mixture of MD, RHA, and cement, which also means MD-cement, MDRHA additions RHA-Cement slightly decrease the OMC and increase the MDD for both soil samples. However, at (2\% MD+6\%RHA, $8 \%$ RHA and 2\%RHA+6\%Cement), the MDD of the soil unexpectedly decrease, and at $8 \%$ RHA, the OMC increases, which might be due to data registration problem or some technical problem during 
laboratory testing. Based on the below Figure 11 shown below, the MDD shows slight increases, and OMC decreases the treatment of weak subgrade soil with MD-cement, MD-RHA, and RHA-Cement additive agents. The MDD increases from $1.296 \mathrm{~g} / \mathrm{cm}^{3}$ to $1.403 \mathrm{~g} / \mathrm{cm}^{3}$ and $\mathrm{OMC}$ decreases from $38 \%$ to $27.54 \%$.

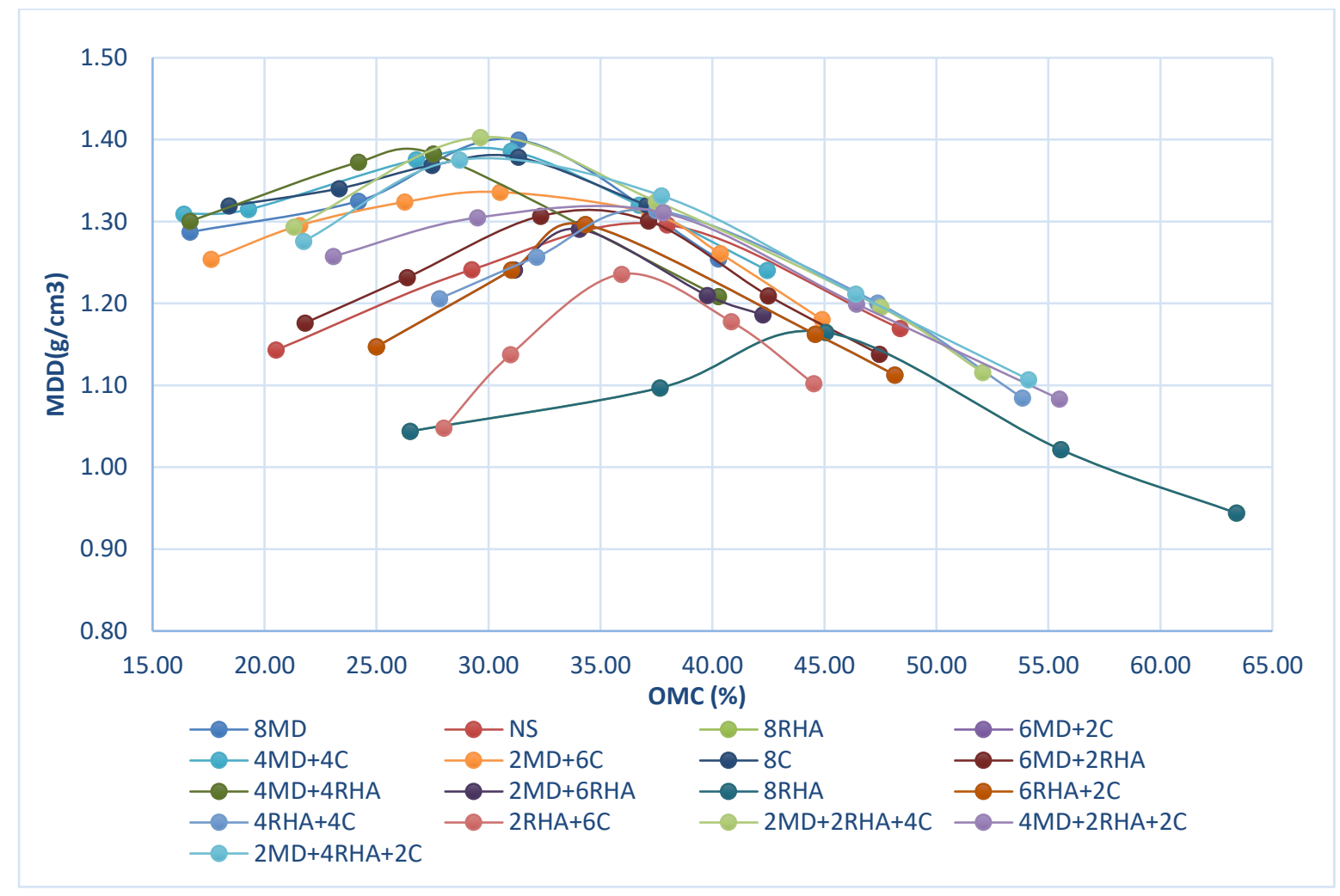

Figure 11 Summary of OMC and MDD for treated soil sample of GTC

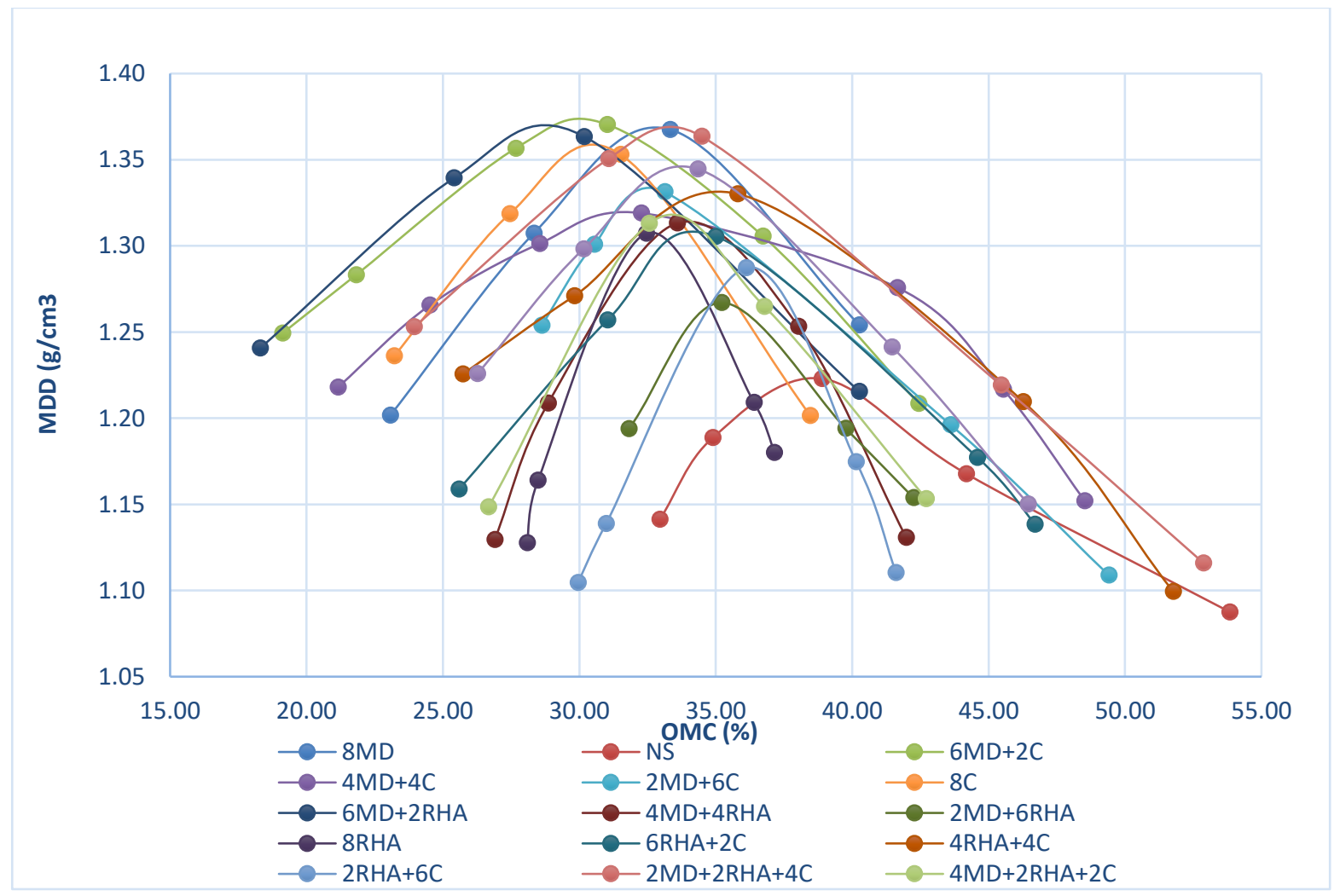

Figure 12 Summary of OMC and MDD for treated soil sample of MSS 
According to the above Figure 12, the MDD shows small increases, and OMC reduces poor subgrade soil treatment with MD-cement, MD-RHA, RHA-Cement, MD-RHA-Cement additives. The MDD rises to $1.37 \mathrm{~g} / \mathrm{cm}^{3}$ from $1.223 \mathrm{~g} / \mathrm{cm}^{3}$, and $\mathrm{OMC}$ falls from $38.89 \%$ to $30.18 \%$.

\subsubsection{CBR test results}

CBR is a parameter which is used to measure the strength of sub-grade soil. The CBR tests were conducted with the addition of the mixed of MD-Cement, MD-RHA, and RHA-Cement. The Specimens are molded at respective optimum moisture content as determined in moisture density relationships. One-point CBR with 56 blows and 4 days (96 hours) socking is conducted and CBR value at 100\% MDD is determined for all tests. The soaked CBR test results for different percentage of MD-Cement, MD-RHA, RHA-cement, MD-RHA-cement are summarized in the Tables 12 below.

Table 12 CBR test results of treated soil sample

\begin{tabular}{|c|c|c|c|c|c|c|c|c|c|}
\hline \multirow{2}{*}{$\begin{array}{c}\text { Sample } \\
\text { Name }\end{array}$} & \multicolumn{3}{|c|}{$\begin{array}{l}\text { Mix proportion of MD, RHA } \\
\text { and Cement }\end{array}$} & \multicolumn{2}{|c|}{$\begin{array}{c}\text { CBR value (\%) } \\
\left(\mathrm{g} / \mathrm{cm}^{3}\right) \\
\text { below } 56\end{array}$} & \multicolumn{2}{|c|}{$\begin{array}{l}\text { Repeated CBR } \\
\text { below } 56\end{array}$} & \multirow{2}{*}{$\begin{array}{c}\text { Ethiopian } \\
\text { road } \\
\text { authority } \\
\text { manual } \\
(\mathbf{2 0 1 3 )} \\
\text { Requirement }\end{array}$} & \multirow{2}{*}{ Remarks } \\
\hline & MD,\% & RHA, \% & Cement,\% & $2.54 \mathrm{~mm}$ & $5.0 \mathrm{~mm}$ & $2.54 \mathrm{~mm}$ & $5.0 \mathrm{~mm}$ & & \\
\hline \multirow{17}{*}{ GTC } & 0 & 0 & 0 & 2.265 & 1.91 & & & \multirow{17}{*}{$>5 \%$} & Poor \\
\hline & 8 & 0 & 0 & 3.644 & 3.21 & & & & poor \\
\hline & 6 & 0 & 2 & 8.515 & 6.26 & & & & Satisfied \\
\hline & 4 & 0 & 4 & 5.220 & 6.55 & 6.46 & 8.98 & & Satisfied \\
\hline & 2 & 0 & 6 & 7.106 & 10.97 & 7.58 & 10.26 & & Satisfied \\
\hline & 0 & 0 & 8 & 6.985 & 12.56 & 2.33 & 4.81 & & Satisfied \\
\hline & 6 & 2 & 0 & 5.220 & 3.81 & & & & Satisfied \\
\hline & 4 & 4 & 0 & 8.318 & 5.29 & & & & Satisfied \\
\hline & 2 & 6 & 0 & 8.485 & 5.95 & & & & Satisfied \\
\hline & 0 & 8 & 0 & 5.152 & 3.73 & & & & satisfied \\
\hline & 0 & 6 & 2 & 8.758 & 6.73 & & & & Satisfied \\
\hline & 0 & 4 & 4 & 9.205 & 6.73 & & & & Satisfied \\
\hline & 0 & 2 & 6 & 11.068 & 8.77 & & & & Satisfied \\
\hline & 0 & 0 & 8 & 6.985 & 12.56 & 2.33 & 4.81 & & Satisfied \\
\hline & 2 & 2 & 4 & 9.091 & 7.65 & & & & Satisfied \\
\hline & 4 & 2 & 2 & 7.576 & 6.44 & & & & Satisfied \\
\hline & 2 & 4 & 2 & 8.508 & 6.43 & & & & Satisfied \\
\hline \multirow{17}{*}{ MSS } & 0 & 0 & 0 & 2.121 & 1.80 & & & \multirow{17}{*}{$>5 \%$} & poor \\
\hline & 8 & 0 & 0 & 3.720 & 3.26 & & & & poor \\
\hline & 6 & 0 & 2 & 7.750 & 6.28 & & & & Satisfied \\
\hline & 4 & 0 & 4 & 9.864 & 7.22 & & & & Satisfied \\
\hline & 2 & 0 & 6 & 10.273 & 9.12 & & & & Satisfied \\
\hline & 0 & 0 & 8 & 11.538 & 9.01 & & & & Satisfied \\
\hline & 6 & 2 & 0 & 5.303 & 3.88 & & & & Satisfied \\
\hline & 4 & 4 & 0 & 8.144 & 6.42 & & & & Satisfied \\
\hline & 2 & 6 & 0 & 8.333 & 5.95 & & & & Satisfied \\
\hline & 0 & 8 & 0 & 5.220 & 4.12 & & & & Satisfied \\
\hline & 0 & 6 & 2 & 7.750 & 6.38 & & & & Satisfied \\
\hline & 0 & 4 & 4 & 10.955 & 9.55 & & & & Satisfied \\
\hline & 0 & 2 & 6 & 11.311 & 9.18 & & & & Satisfied \\
\hline & 0 & 0 & 8 & 11.538 & 9.01 & & & & Satisfied \\
\hline & 2 & 2 & 4 & 9.598 & 8.06 & & & & Satisfied \\
\hline & 4 & 2 & 2 & 8.000 & 6.29 & & & & Satisfied \\
\hline & 2 & 4 & 2 & 8.909 & 6.43 & & & & Satisfied \\
\hline
\end{tabular}


As shown in Table 12, CBR result showed that the significant improvement in strength compared to untreated soil sample. Results indicated that the CBR values of treated soils with MD-cement, RHA-cement, MD-RHA-cement, MD-RHA mix increases as the quantity of cement increases rather than the MD and RHA. However, according to ERA pavement design manual specification, the CBR values of treated soil with $8 \%$ RHA alone is full fill the specification as a subgrade material but the $8 \%$ MD not fulfill the ERA specification. The significant increase in CBR value may attributed to reactions between cement, MD, RHA, soil and water. Stabilization of weak subgrade soil with MD, RHA and cement combination is a new concept that is the reaction of MD, RHA, cement, soil and water is scanty in the literature. Therefore; one or more the following mechanisms cation exchange, hydration reaction, pozzolanic reaction, adhesive property of MD and RHA may be responsible for significant increase in CBR values.

\subsubsection{CBR swell for stabilized soil samples}

The swells of expansive soil samples mixed with MD-Cement, RHA-Cement, MD-RHA are measured and determined from soils. The percentage combination of MD and cement, RHA and cement, MD are RHA was performed on CBR tests, from which swell measurement are taken at the time of soaking and after four days of soaking.

Table 13 Swell value from CBR test

\begin{tabular}{|c|c|c|c|c|c|c|}
\hline $\begin{array}{l}\text { Sample } \\
\text { Name }\end{array}$ & Mix pro & $\begin{array}{l}\text { ion of } \mathrm{Ml} \\
\text { Cement }\end{array}$ & RHA and & $\begin{array}{c}\text { CBR Swell } \\
\%\end{array}$ & $\begin{array}{c}\text { ERA } \\
\text { Requirement }\end{array}$ & Remark \\
\hline \multirow{18}{*}{ GTC } & MD,\% & RHA, \% & Cement, \% & & & \\
\hline & 0 & 0 & 0 & 4.29 & \multirow{17}{*}{$<2 \%$} & Poor \\
\hline & 8 & 0 & 0 & 2.49 & & Poor \\
\hline & 6 & 0 & 2 & 1.80 & & Satisfied \\
\hline & 4 & 0 & 4 & 1.72 & & Satisfied \\
\hline & 2 & 0 & 6 & 1.46 & & Satisfied \\
\hline & 0 & 0 & 8 & 1.12 & & Satisfied \\
\hline & 6 & 2 & 0 & 1.89 & & Satisfied \\
\hline & 4 & 4 & 0 & 1.85 & & Satisfied \\
\hline & 2 & 6 & 0 & 1.72 & & Satisfied \\
\hline & 0 & 8 & 0 & 1.72 & & Satisfied \\
\hline & 0 & 6 & 2 & 1.72 & & Satisfied \\
\hline & 0 & 4 & 4 & 1.55 & & Satisfied \\
\hline & 0 & 2 & 6 & 1.46 & & Satisfied \\
\hline & 0 & 0 & 8 & 1.12 & & Satisfied \\
\hline & 2 & 2 & 4 & 1.63 & & Satisfied \\
\hline & 4 & 2 & 2 & 1.76 & & Satisfied \\
\hline & 2 & 4 & 2 & 1.72 & & Satisfied \\
\hline \multirow{17}{*}{ MSS } & 0 & 0 & 0 & 4.90 & \multirow{17}{*}{$<2 \%$} & Poor \\
\hline & 8 & 0 & 0 & 2.75 & & Satisfied \\
\hline & 6 & 0 & 2 & 1.80 & & Satisfied \\
\hline & 4 & 0 & 4 & 1.37 & & Satisfied \\
\hline & 2 & 0 & 6 & 1.37 & & Satisfied \\
\hline & 0 & 0 & 8 & 1.29 & & Satisfied \\
\hline & 6 & 2 & 0 & 1.98 & & Satisfied \\
\hline & 4 & 4 & 0 & 1.80 & & Satisfied \\
\hline & 2 & 6 & 0 & 1.72 & & Satisfied \\
\hline & 0 & 8 & 0 & 1.89 & & Satisfied \\
\hline & 0 & 6 & 2 & 1.63 & & Satisfied \\
\hline & 0 & 4 & 4 & 1.33 & & Satisfied \\
\hline & 0 & 2 & 6 & 1.29 & & Satisfied \\
\hline & 0 & 0 & 8 & 1.29 & & Satisfied \\
\hline & 2 & 2 & 4 & 1.20 & & Satisfied \\
\hline & 4 & 2 & 2 & 1.63 & & Satisfied \\
\hline & 2 & 4 & 2 & 1.55 & & Satisfied \\
\hline
\end{tabular}


The above Table 13 show that the soil sample with the various percentage of MD-cement, RHA-cement, MD-RHA mix ratio and $8 \%$ of MD, RHA and cement was conducted. As a result, all the above mix ratios and the MD, RHA and cement alone for both soil samples have met the requirements specified by the Ethiopian road design manual of pavement design.

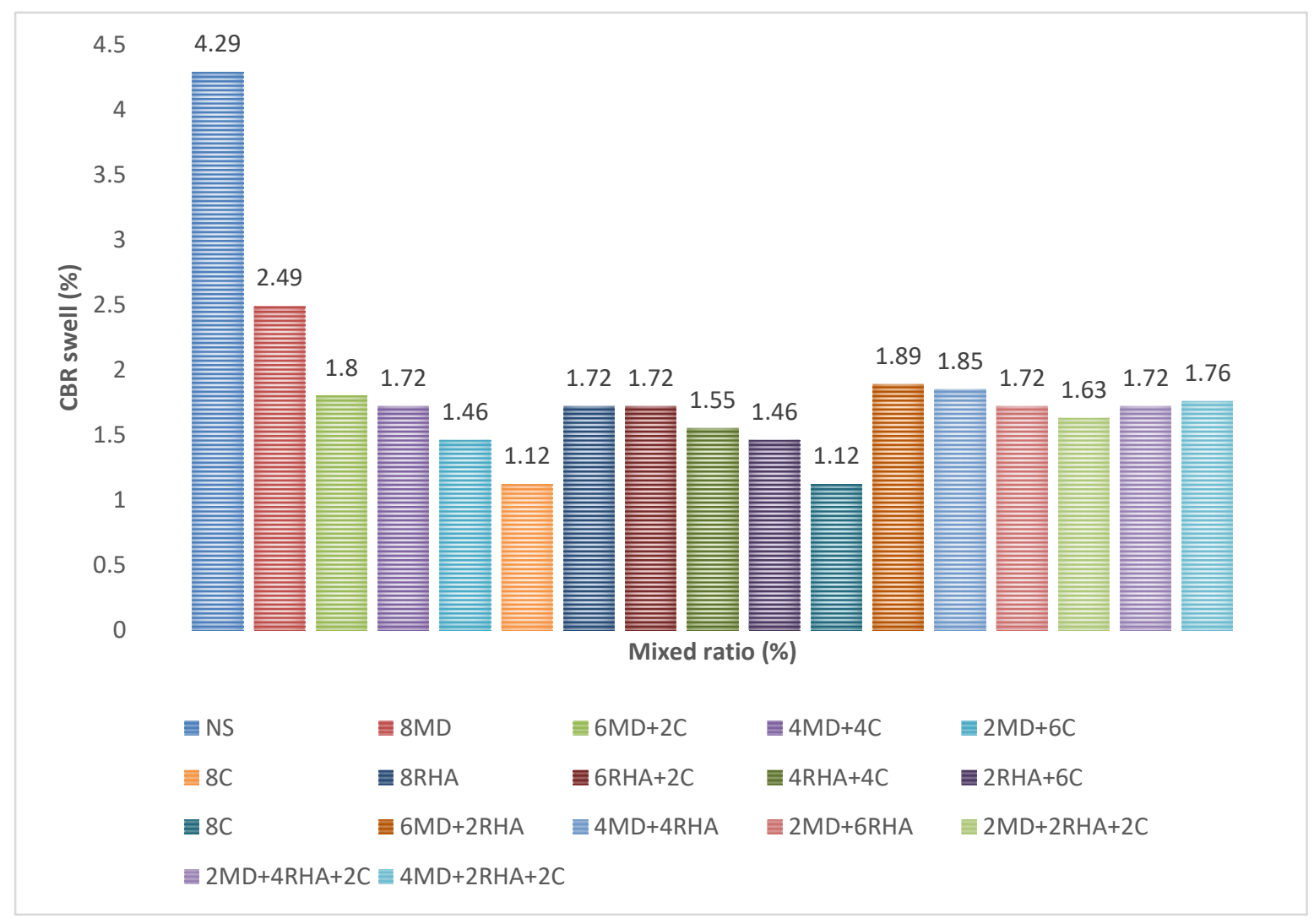

Figure 13 Summary of CBR swells for GTC soil sample.

The expansive soil treated with the mixed ratio of MD-cement, RHA-cement, MD-RHA, and 8\% MD and RHA alone showed the reduction of CBR swell compared to $4.29 \%$ and $4.90 \%$ of untreated soil for GTC and MSS soil sample, respectively. The soil was treated with $(8 \mathrm{MD}, 6 \mathrm{MD}+2 \mathrm{C}, 4 \mathrm{MD}+4 \mathrm{C}, 2 \mathrm{MD}+6 \mathrm{C}, 8 \mathrm{C}, 8 \mathrm{RHA}, 6 \mathrm{RHA}+2 \mathrm{C}, 4 \mathrm{RHA}+4 \mathrm{C}, 2 \mathrm{RHA}+6 \mathrm{C}, 6 \mathrm{MD}+2 \mathrm{RHA}, 4 \mathrm{MD}+4 \mathrm{RHA}, 2 \mathrm{M}$ $\mathrm{D}+6 \mathrm{RHA}, 2 \mathrm{MD}+2 \mathrm{RHA}+4 \mathrm{C}, 2 \mathrm{MD}+4 \mathrm{RHA}+2 \mathrm{C}, 4 \mathrm{MD}+2 \mathrm{RHA}+2 \mathrm{C}) \mathrm{RHA}$-cement yielded a significant reduction in CBR swelled when it compared to the mixed ratio of MD-cement, MD-RHA and from the $8 \%$ CBR swell of MD and RHA alone.

The CBR swell decreases when increasing the percentage of cement in the mixture ratio for all mixed ratios for both soil samples. Also, the CBR swell reduced with increasing the RHA rather than MD. The CBR swell for all mixed ratio with its reduction are shown in Figure 13 and Figure 14. In general, these decreases swell characteristics are due to a decrease preference for calcium saturated clay water and the development of a cementitious matrix that prevents volumetric expansions. 


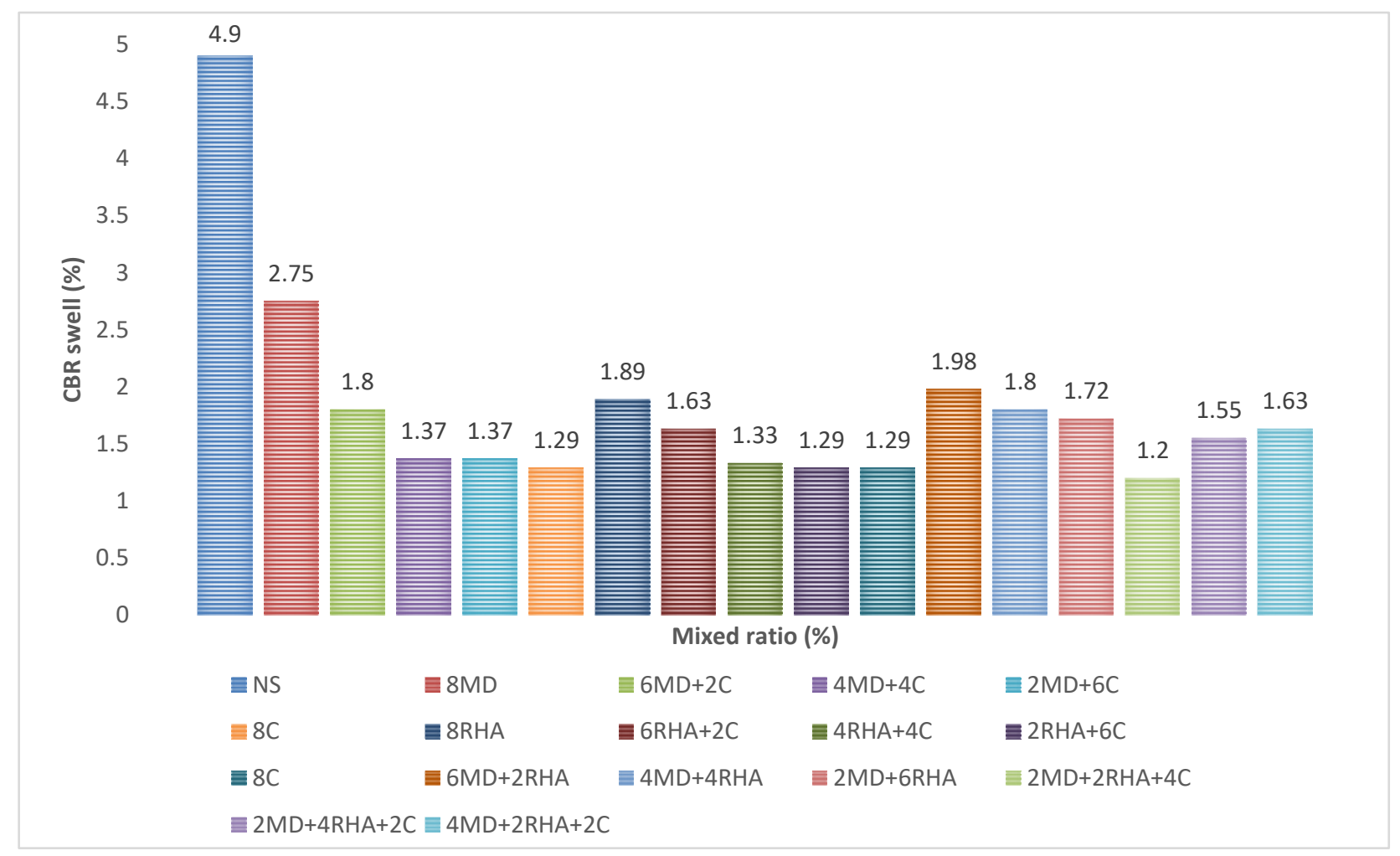

Figure 14 Summary of CBR swells for MSS soil sample.

\subsection{CONCLUSIONS}

- The chemical composition of RHA and MD test result indicates the chemical composition of main oxides $\left(\mathrm{SiO}_{2}\right.$ $+\mathrm{Al}_{2} \mathrm{O}_{3}+\mathrm{Fe}_{2} \mathrm{O}_{3}$ ) were $70.13 \%$ and $42.43 \%$, respectively, which is above the minimum of $(70 \%)$ specified by ASTM (C618) standard specification to be satisfied as minimum requirement of Natural Pozzolanic materials

- The general soil classification systems, AASHTO and USCS, show A-7-5 and CH, respectively. This indicates that the soils are poor and unsuitable to use as the subgrade road construction material unless it is treated.

- The additives mixed ratio (MD-cement, RHA-cement, MD-cement) and the 8\% MD, RHA and cement alone decreases the LL and PI for both untreated soil samples. The LL decreases with slight changes for both soil samples from control value 73.4\%-56.97\% and 79.70\%-56.51\% for GTC and MSS soil samples, respectively. The PL increases with stabilization of additives of the Mix-ratio from control value $30.68 \%-53.26 \%$ and $30.91 \%-53.51 \%$ for GTC and MSS soil sample respectively; however, PL of both soil samples radically increase when the mix-ratio of cement increases rather than MD and RHA. The PI decreased from $42.72 \%$ to $4.62 \%$ and from $48.79 \%$ to $6.15 \%$ GTC and MSS soil samples, respectively. Also, in the MD-RHA mixed ratio, the liquid limit decreases when increasing the RHA and the plastic index decreases when increasing the RHA for both soil samples. The stabilizers (MD, RHA and cement) significantly change the PI, not significantly changing the LL. This means that all treated soil samples fulfill the ERA specification according to PI.

- The MDD increases slightly, and OMC decreases in the treatment of weak sub-grade soil samples with (RHAcement, MD-cement, MD-RHA-cement, MD-RHA) additive agents. For GTC treated soil sample, the MDD increases from $1.296 \mathrm{~g} / \mathrm{cm}^{3}$ to $1.403 \mathrm{~g} / \mathrm{cm}^{3}$ and OMC decreases from $38 \%$ to $27.54 \%$. The MDD increases from $1.223 \mathrm{~g} / \mathrm{cm}^{3}$ to $1.37 \mathrm{~g} / \mathrm{cm}^{3}$ and OMC decreases from $38.89 \%$ to $30.18 \%$ for MSS soil sample. Increasing the percentage of cement in the mixed ratio leads to increasing the MDD and decreasing OMC for all mix-ratio rather than other additives (MD and RHA).

- Soil treated with rice husk ash showed substantial improvement. Soil treated with $8 \%$ rice husk ash gave CBR value of $5.152 \%$ from a value of $2.265 \%, 5.220 \%$ from the value of $2.121 \%$ and the CBR swell of $1.72 \%$ from $4.29 \%$ and $1.89 \%$ from $4.90 \%$ for GTC and MSS the natural soil respectively showed that strength of the expansive soil substantially improved and swelling potential decreased considerably. The soil treated with MD alone not satisfied the ERA requirement, so that MD alone cannot be used as a stabilizer, but it could be treated mixed with RHA and cement. Furthermore, as the CBR value (\%) increases with increasing the cement percentage in a mixed ratio (MD-cement, RHA-cement MA-RHA-cement), comparatively, the CBR value of 
RHA-Cement mixed ratio greater than the other mixed ratio. However, according to the ERA specification, all proportions of mix ratios met the minimum specifications used as a road subgrade material.

- All mixing stabilizers (MD-cement, RHA-cement, MD-RHA, MD-RHA-cement) and 8\% of RHA and cement fulfill the ERA specification requirements for CBR swell value. However, $8 \%$ of marble dust alone does not fulfill the Ethiopia road authority requirements for CBR swell. The MD and RHA standalone not improving some of the engineering properties of soil samples used for subgrade construction. However, they mixed with different percentages of cement can effectively stabilizer for this expansive soil.

\section{Acknowledgement}

The authors wish to thank the Jimma Institute of Technology, Jimma University in providing the necessary support for carrying out this research study.

\section{References}

[1] Bah, E. M., Faye, I., \& Geh, Z. F. (2018). The Construction Cost Conundrum in Africa. In E. M. Bah, I. Faye, \& Z. F. Geh, Housing Market Dynamics in Africa (pp. 159-214). Palgrave Macmillan UK. https://doi.org/10.1057/978-1137-59792-2_5

[2] Akadiri, P. O., Chinyio, E. A., \& Olomolaiye, P. O. (2012). Design of A Sustainable Building: A Conceptual Framework for Implementing Sustainability in the Building Sector. Buildings, 2(2), $126-152$. https://doi.org/10.3390/buildings2020126

[3] Shi, B., Jiang, H., Liu, Z., \& Fang, H. Y. (2002). Engineering geological characteristics of expansive soils in China. Engineering Geology, 67(1-2), 63-71. https://doi.org/10.1016/S0013-7952(02)00145-X

[4] Ikeagwuani, C. C., \& Nwonu, D. C. (2019). Emerging trends in expansive soil stabilisation: A review. Journal of Rock Mechanics and Geotechnical Engineering, 11(2), 423-440. https://doi.org/10.1016/j.jrmge.2018.08.013

[5] Geremew, A., \& Fayissa, B. (2018). Experimental Performance Studies on the Improved Expansive Subgrade Soil Formation by Using Mechanical Stabilization with Natural Gravel Around Jimma Quarry Sites. American Journal of Civil Engineering, 6(5), 154-161. https://doi.org/10.11648/j.ajce.20180605.13

[6] Jemal, A., Agon, E. C., \& Geremew, A. (2019). Utilization Of Crushed Stone Dust As A Stabilizer For Sub Grade Soil: A Case Study In Jimma Town. International Journal of Engineering, XVII(4), 55-64.

[7] She, J., Lu, Z., Yao, H., Fang, R., \& Xian, S. (2019). Experimental Study on the Swelling Behavior of Expansive Soil at Different Depths under Unidirectional Seepage. Applied Sciences, 9(6), 1233. https://doi.org/10.3390/app9061233

[8] Geremew, A., Quezon, E. T., \& Kebede, G. (2016). Influence Of Subsurface Courses Materials On Pavement Performance: A Case Study in Yebu-Agaro Road. International Journal of Scientific \& Engineering Research, 7(10), 1252-1260.

[9] Viswanadham, B. V. S., Phanikumar, B. R., \& Mukherjee, R. V. (2009). Swelling behaviour of a geofiber-reinforced expansive soil. Geotextiles and Geomembranes, 27(1), 73-76. https://doi.org/10.1016/j.geotexmem.2008.06.002

[10] Thyagaraj, T. (Ed.). (2019). Ground Improvement Techniques and Geosynthetics: IGC 2016 Volume 2 (Vol. 14). Springer Singapore. https://doi.org/10.1007/978-981-13-0559-7

[11] Phanikumar, B. R., \& Singla, R. (2016). Swell-consolidation characteristics of fibre-reinforced expansive soils. Soils and Foundations, 56(1), 138-143. https://doi.org/10.1016/j.sandf.2016.01.011

[12] Dinka, O. G., Agon, E. C., \& Geremew, A. (2019). Performance Studies on Subgrade Formation Using Lime and Cement in Road Projects. Applied Journal of Environemntal Engineering Science, 5(4), 420-436. https://doi.org/10.48422/IMIST.PRSM/ajees-v5i4.17836

[13] Mesfun, R. T., Quezon, E. T., \& Geremew, A. (2019). Experimental Study Of Stabilized Expansive Soil Using Pumice Mixed With Lime For Subgrade Road Construction. International Journal of Research -GRANTHAALAYAH, 7(7), 118-124. https://doi.org/10.29121/granthaalayah.v7.i7.2019.736

[14] Gupta, C., \& Sharma, D. R. K. (2014). Influence of Marble Dust, Fly Ash and Beas Sand on Sub Grade Characteristics of Expansive Soil. IOSR Journal of Mechanical and Civil Engineering, 13-18.

[15] Kurdowski, W. (2014). Cement and Concrete Chemistry. Springer Netherlands. https://doi.org/10.1007/978-94-0077945-7

[16] Karim, Md., Hossain, Md., Khan, M., Zain, M., Jamil, M., \& Lai, F. (2014). On the Utilization of Pozzolanic Wastes as an Alternative Resource of Cement. Materials, 7(12), 7809-7827. https://doi.org/10.3390/ma7127809

[17] Gonfa, L. G., Tucay Quezon, E. T. Q., \& Geremew, A. (2020). Experimental Study On Application Of Marble Waste As Conventional Aggregate For Base Course Materials. Journal of Civil Engineering, Science and Technology, 11(2), 144-163. https://doi.org/10.33736/jcest.2620.2020

[18] Seyfe, M., \& Geremew, A. (2019). Potential Use Of Cinder Gravel As An Alternative Base Course Material Through Blending With Crushed Stone Aggregate And Cement Treatment. Journal of Civil Engineering, Science and Technology, 10(2), 101-112. https://doi.org/10.33736/jcest.1465.2019

[19] McCarthy, D. F. (2014). Essentials of soil mechanics and foundations: Basic geotechnics (Seventh edition). Pearson. 
[20] Mamuye, Y., Quezon, E. T., \& Geremew, A. (2018). Combined Effects of Molasses-Lime Treatment on Poor Quality Natural Gravel Materials Used for Sub-Base and Base Course Construction. Global Scientific Journal, 6(7), 621-633. https://doi.org/10.20372/nadre\%2F4245 